\title{
Optical Properties of Near-Surface Urban Aerosols and their Chemical Tracing in a Mediterranean City (Athens)
}

\author{
Dimitris Katsanos $^{1}$, Aikaterini Bougiatioti ${ }^{2,3}$, Eleni Liakakou ${ }^{1}$, Dimitris G. Kaskaoutis ${ }^{1}$, \\ Iasonas Stavroulas ${ }^{1,4}$, Despina Paraskevopoulou ${ }^{1}$, Maria Lianou ${ }^{1}$, Basil E. Psiloglou ${ }^{1}$, \\ Evangelos Gerasopoulos ${ }^{1}$, Christodoulos Pilinis ${ }^{5}$, Nikolaos Mihalopoulos ${ }^{1,2 *}$ \\ ${ }^{I}$ IERSD, National Observatory of Athens, Lofos Koufou, Palaia Penteli, 15236 Athens, Greece \\ ${ }^{2}$ Environmental Chemical Processes Laboratory, Department of Chemistry, University of Crete, 71003 Crete, Greece \\ ${ }^{3}$ School of Earth and Atmospheric Sciences, Georgia Institute of Technology, Atlanta, GA 30332, USA \\ ${ }^{4}$ Energy Environment and Water Research Center, The Cyprus Institute, Nicosia 2121, Cyprus \\ ${ }^{5}$ Department of Environment, University of Aegean, Mytilene 81100, Greece
}

\begin{abstract}
One-year measurements (October 2016-September 2017) of aerosol optical properties in the Athens urban environment were analyzed; for closure purposes, the results were supported by data of chemical composition of the non-refractory submicron aerosol fraction acquired with an Aerosol Chemical Speciation Monitor (ACSM). Both the spectral scattering $\left(b_{\text {sca }}\right)$ and absorption $\left(b_{a b s}\right)$ coefficients exhibit a pronounced annual variability with higher values $\left(63.6 \mathrm{Mm}^{-1}\right.$ at $550 \mathrm{~nm}$ and $41.0 \mathrm{Mm}^{-1}$ at $520 \mathrm{~nm}$, respectively) in winter, due to domestic heating releasing increased carbonaceous emissions and the shallow mixing layer trapping aerosols near the surface. Much lower values $\left(33.5 \mathrm{Mm}^{-1}\right.$ and $22.9 \mathrm{Mm}^{-1}$ for $\mathrm{b}_{\text {sca }}$ and $b_{a b s}$, respectively) are found during summer, indicating rather aged aerosols from regional sources. The estimations of the dry spectral single scattering albedo (SSA), scattering (SAE) and absorption (AAE) Ångström exponents focus on the seasonality of the urban aerosols. The high SAE $(\sim 2.0)$ and low SSA $(0.62 \pm 0.11)$ values throughout the year indicate the dominance of fine-absorbing aerosols from fossil-fuel combustion, while the high AAE $(\sim 1.5)$ in winter suggests enhanced presence of biomass-burning aerosols. Pronounced morning and late evening/night peaks are found in both $b_{\text {sca }}$ and $b_{a b s}$ during winter, coinciding with the morning traffic rush hour and increased residential wood burning in the evening, while in the other seasons, the diurnal patterns flatten out. The wind speed strongly affects the aerosol loading and properties in winter, since for winds below $3 \mathrm{~m} \mathrm{~s}^{-1}$, a high increase in $b_{\text {sca }}$ and $b_{a b s}$ is observed, consistent with low dilution processes and hazy/smoggy conditions. Our closure experiments indicate a good agreement $\left(\mathrm{R}^{2}=0.91\right.$, slope $\left.=1.08\right)$ between the reconstructed and measured $b_{\text {sca }}$ values and reveal that organic matter contributes about half of the sub-micron mass in winter, followed by sulfate $(\sim 40 \%)$ and nitrate $(10 \%$, only in winter) aerosols.
\end{abstract}

Keywords: Urban aerosols; Light scattering; Absorption; Chemical species; Wood burning; Athens.

\section{INTRODUCTION}

Atmospheric aerosols are one of the most important constituents in the earth-atmosphere system and climate (IPCC, 2013). Particulate matter $\left(\mathrm{PM}_{2.5}, \mathrm{PM}_{10}\right)$, carbonaceous aerosols (Organic Matter (OM), Black Carbon (BC), Brown Carbon (BrC)) and gaseous air pollutants in urban environments contribute significantly to the light scattering and absorption processes, leading to large reduction in surface solar radiation, deterioration of visibility and air quality, and modification of the radiation and energy

\footnotetext{
* Corresponding author.

E-mail address: nmihalo@noa.gr
}

balance with significant impacts on local and regional climate (Antón et al., 2012; Bisht et al., 2015; Valenzuela et al., 2015; Zhang et al., 2017). For assessing the climatic impact of aerosols, specific knowledge of the aerosol scattering $\left(b_{\mathrm{sca}}\right)$, absorption $\left(\mathrm{b}_{\mathrm{abs}}\right)$ coefficients and single scattering albedo (SSA) is required (Moosmüller et al., 2012; Dumka and Kaskaoutis, 2014). Aerosol studies over Greece mostly have focused on examining the columnar aerosol loading, physical-chemical and optical properties, types, source regions and climate implications (e.g., Gerasopoulos et al., 2003, 2007, 2011; Papadimas et al., 2012), while special attention has been given to Saharan dust storms (e.g., Gkikas et al., 2013; Athanasopoulou et al., 2016; Diapouli et al., 2017a; Kosmopoulos et al., 2017).

Apart from the decreasing trends in industrial and traffic emissions $\left(\mathrm{NO}_{2}, \mathrm{SO}_{2}\right)$ due to economic recession in Greece 
(e.g., Vrekoussis et al., 2013), the Athens Basin and other Greek cities experienced enhanced emissions of carbonaceous aerosols from bio-fuel and wood burning for residential heating during the last winter periods (Saffari et al., 2013; Sarigiannis et al., 2015; Gratsea et al., 2017; Panopoulou et al., 2017). In this line, synergy of ground-based measurements and modelling techniques has been utilized to study the carbonaceous-aerosol characteristics over Athens and to address their source apportionment and impact on regional air quality (e.g., Remoundaki et al., 2013; Pateraki et al., 2014; Saraga et al., 2015; Triantafyllou et al., 2016; Athanasopoulou et al., 2017; Grivas et al., 2018). Several studies have shown an increase in the carbonaceous-aerosol and PM concentrations during the recent years, especially during the winter periods (Paraskevopoulou et al., 2014; Diapouli et al., 2017b; Theodosi et al., 2018), while recent $\mathrm{BC}$ source apportionment studies have shown that the wood burning emissions $\left(\mathrm{BC}_{\mathrm{wb}}\right)$ contribute about $20-33 \%$ to the total $\mathrm{BC}$ mass in Athens Basin during wintertime (Diapouli et al., 2017c; Fourtziou et al., 2017; Kalogridis et al., 2018). However, the near-surface aerosol optical and physical properties have not been evaluated so far, thus leaving a knowledge gap about their characteristics, seasonality and radiative impact. Few studies in the past examined the near-surface aerosol properties at the remotecoastal station of Finokalia, Crete (Sciare et al., 2005; Vrekoussis et al., 2005; Kalivitis et al., 2011), while data from a suburban site (Democritos, Athens) has been involved in a European scale study (Pandolfi et al., 2018), still not exploring the aerosol absorption characteristics or the SSA.

This study analyzes, for the first time, the annual characteristics of the near-surface extensive and intensive properties (i.e., $b_{\mathrm{sca}}, \mathrm{b}_{\mathrm{abs}}$, SAE, AAE, SSA) of urban aerosols, obtained via systematic in-situ measurements in downtown Athens, aiming to examine the seasonality, the diurnal patterns, as well as to assess the influence of meteorology and emission sources, including residential wood burning, on aerosol loading and characteristics. Furthermore, it examines the role and contribution of major chemical species (organics, ammonium, sulfate, nitrate) on aerosol scattering.

\section{STUDY LOCATION, MEASUREMENTS AND TECHNIQUES}

\section{Measuring Site}

Measurements were conducted at the urban background station of the National Observatory of Athens (NOA; $37.97^{\circ} \mathrm{N}, 23.72^{\circ} \mathrm{E}, 105 \mathrm{~m}$ a.s.l.) at Thissio, a site that is considered as receptor of pollution plumes of different origins (Paraskevopoulou et al., 2015; Theodosi et al., 2018). This station is operated for measuring the background pollution levels in the Athens Basin and for assessing the sources of the transported aerosol plumes, since it is far from industries, main avenues and traffic zones (Gratsea et al., 2017; Fourtziou et al., 2017). More information about the morphology of the Athens Basin, the prevailing meteorological and dominant aerosol patterns can be found elsewhere (e.g., Kanakidou et al., 2011; Theodosi et al., 2011).

\section{Instrumentation and Measurements}

A three wavelength $(450,550,700 \mathrm{~nm})$ Integrating Nephelometer (model: TSI, 3563) was used for the measurement of the aerosol scattering coefficient $\left(b_{\text {sca }}\right.$ in $\mathrm{Mm}^{-1}$; between $7^{\circ}$ and $170^{\circ}$ ) during the period October 2016-September 2017, averaged at 1-hour time intervals. As the grand majority $(87 \%)$ of the Nephelometer measurements lies below $40 \% \mathrm{RH}$ and $97 \%$ of the data lies below 50\% RH, the derived aerosol properties that are analyzed in this study are regarded as corresponding to dry conditions. The Nephelometer was calibrated prior to the beginning of the measurements using $\mathrm{CO}_{2}$ as the high span gas and air as the low span gas, with the calibration constant lying within $\sim 2 \%$ and the overall uncertainty in the $b_{\text {sca }}$ being 7\% (Heintzenberg et al., 2006; Pandolfi et al., 2018).

Continuous measurements of spectral aerosol absorption coefficient $\left(b_{\mathrm{abs}}\right.$ in $\left.\mathrm{Mm}^{-1}\right)$ were also carried out at NOA, Thissio, from October 2016 to September 2017, using a dual-spot seven-wavelength $(370,470,520,590,660,880$ and $950 \mathrm{~nm}$ ) Aethalometer (AE-33; Drinovec et al., 2015). The AE-33 provides real-time measurements for the multiple scattering and loading effects using a dual-spot technology, where the incoming flow is split into two streams with unequal flows and passes through two spots on the same filter tape (Vaishya et al., 2017; Kalogridis et al., 2018). Therefore, AE-33 has the advantage of avoiding manual post-processing of the $b_{\text {abs }}$ due to loading effect, while it uses an internal multiple-scattering correction of $C$ $=1.57$ (Drinovec et al., 2015; Rajesh and Ramachandran, 2018). Some studies have shown that the $C=1.57$ is small and results in overestimation of the $b_{a b s}$ (Collaud Coen et al., 2010; Kumar et al., 2018), while Rajesh and Ramachandran (2018) reported an overestimation of $28.5 \%$ in the $b_{a b s}$ from AE-33 against AE-31 in urban Ahmedabad, India. Although AE-33 initially measures the $b_{a b s}$, the instrument output (BC in $\mu \mathrm{g} \mathrm{m}^{-3}$ ) is finally used for the estimation of the spectral $b_{\mathrm{abs}}$ via the mass absorption cross section (MAC) values (Backman et al., 2017; Rajesh and Ramachandran, 2018):

$\mathrm{b}_{\mathrm{abs}}=\mathrm{BC} \times \mathrm{MAC}$

The MAC values for AE-33 at 370, 470, 880 and $950 \mathrm{~nm}$ were $18.47,14.54,7.77$ and $7.16 \mathrm{~m}^{2} \mathrm{~g}^{-1}$, respectively, taken from the manufacturer. The overall uncertainty in the $b_{a b s}$ retrievals is in the range of $10-15 \%$ and seems to equally affect each wavelength, thus not altering the spectral dependence of the $b_{\text {abs }}$ (Collaud Coen et al., 2010; Sciare et al., 2011).

\section{Ancillary Measurements}

\section{On-Line Aerosol, Gaseous and Meteorological} Measurements

Aerosol chemical composition analysis was performed using an Aerosol Chemical Speciation Monitor (ACSM; $\mathrm{Ng}$ et al., 2011) that was collocated with the measurements of the aerosol optical properties. The ACSM measures the mass of particulate ammonium $\left(\mathrm{NH}_{4}^{+}\right)$, nitrate $\left(\mathrm{NO}_{3}{ }^{-}\right)$, sulfate $\left(\mathrm{SO}_{4}{ }^{2-}\right)$, chloride $\left(\mathrm{Cl}^{-}\right)$and $\mathrm{OM}$, providing near realtime chemical compositions at $30-\mathrm{min}$ resolution. Details 
about the ACSM measurements, time series and seasonal variability can be found elsewhere (Stavroulas et al., 2018). The ACSM measurements were used for the reconstruction of the aerosol $b_{\text {sca }}$ and to evaluate the contribution of each individual component on light scattering.

Complementary to the ACSM measurements, carbon monoxide (CO) and nitrogen monoxide (NO) were also monitored, at 1-min resolution, by a Horiba APMA-360 series automatic gas analyzer (scale: 0-10 ppmv, lower detectable limit: 0.2 ppmv, precision: $\pm 0.2 \mathrm{ppmv}$ ) and a Horiba APNA-360 series (chemiluminescence technique, scale: $0-1000$ ppbv, lower detectable limit: $0.5 \mathrm{ppbv}$ ), respectively. $\mathrm{PM}_{10}$ concentrations were measured at 1-min resolution using a beta-attenuation monitor (Eberline, $\mathrm{FH}$ 62 I-R). Finally, meteorological data (ambient temperature, relative humidity, precipitation, wind speed (WS) and direction) at the sampling site were recorded by NOA's automatic meteorological station (1-min resolution).

\section{Off-Line Aerosol Measurements}

$\mathrm{PM}_{2.5}$ aerosol samples were collected using a Derenda particle sampler, with sampling time of 12 hours during the period November to February, and 24 hours during the remaining period (March to October). Samples were collected on 47-mm quartz filter samples (Tissuquartz, 2500QAT-UP, PALL). The $\mathrm{PM}_{2.5}$ mass was determined by gravimetric analysis using an analytical microbalance with a precision of $1 \mu \mathrm{g}(\mu \mathrm{X}-5$, Mettler-Toledo, Inc.). The filters were conditioned for 48 hours in controlled temperature $\left(20 \pm 3^{\circ} \mathrm{C}\right)$ and $\mathrm{RH}(40 \pm 5 \%)$ conditions before pre- and post-weighing, according to the United States Environmental Protection Agency manual reference method: RFPS-1298126 (Paraskevopoulou et al., 2014).

\section{Retrieved Parameters}

The measured aerosol $b_{\text {sca }}$ and $b_{a b s}$ are referred as "extensive properties" because they are linked to the number of aerosols in the atmosphere. These measurements were used to determine several other aerosol variables (known as "intensive properties"), such as the scattering Ångström exponent (SAE), absorption Ångström exponent (AAE) and SSA, which are related to size, shape, hygroscopic behavior, chemical composition and radiative impacts of aerosols rather than the aerosol loading (Dumka et al., 2015). The SAE was calculated using the multi-wavelength Nephelometer $b_{\text {sca }}$ measurements by applying the equation:

$$
S A E=-\frac{\ln \left(b_{s c a}\left(\lambda_{1}\right) / b_{s c a}\left(\lambda_{2}\right)\right)}{\ln \left(\lambda_{1} / \lambda_{2}\right)}
$$

where $\lambda_{1}$ and $\lambda_{2}$ are the wavelengths corresponding to the pairs $450 / 550,450 / 700$ and $550 / 700 \mathrm{~nm}$. SAE is an indicator of the dependence of scattering on particle size, with values higher than 1.5-2 implying scattering by submicron aerosols and values lower than 1 indicative of coarse particles (e.g., Valenzuela et al., 2015).

Similarly, the AAE values were computed using the negative slope of a log-log plot of $b_{a b s}$ vs wavelength, as
$\mathrm{AAE}=-\mathrm{d} \ln \left(\mathrm{b}_{\mathrm{abs}}(\lambda)\right) / \mathrm{d} \ln (\lambda)$, in three wavelength bands, namely, $370-880 \mathrm{~nm}, 370-520 \mathrm{~nm}$ and $520-880 \mathrm{~nm}$, in order to examine in higher detail the wavelength dependence of the absorption and the associated aerosol sources. Titos et al. (2017) also used the wavelength ranges $370-950 \mathrm{~nm}$ and 370-520 nm for the AAE estimates, since the $\mathrm{AAE}_{370-520}$ is much more sensitive to changes in the spectral dependence of the $b_{a b s}$ at shorter wavelengths.

The spectral SSA was calculated as:

$$
S S A=\frac{b_{s c a}}{b_{s c a}+b_{a b s}}
$$

at three wavelengths (450, 550 and $700 \mathrm{~mm})$ coinciding with the Nephelometer $b_{\text {sca }}$ values, by using concurrent measurements from the two instruments. The $b_{\text {abs }}$ values at 450, 550 and $700 \mathrm{~nm}$ were estimated via the Ångström's formula using the neighboring $\mathrm{b}_{\mathrm{abs}}$ values (i.e., 470, 520, $660 \mathrm{~nm}$ ) and the AAE in the spectral band $370-880 \mathrm{~nm}$. The SSA provides useful information about the relative contributions of scattering and absorption to total aerosol extinction, while it is also very important for aerosol radiative forcing and climate modelling studies (Hatzianastassiou et al., 2004). Non-absorbing particles have SSA values close to 1 , implying atmospheric cooling, while low SSA $(<0.6-$ 0.7 ) refers to more absorbing aerosols, like BC, suggesting atmospheric warming (Bisht et al., 2015; Tiwari et al., 2016). The uncertainty in the computed SSA values, due to the combined effects of the measurement errors and uncertainties in the interpolation of the $b_{a b s}$, ranges between $10 \%$ and $15 \%$, with larger errors for low $b_{\text {sca }}$ and $b_{\text {abs }}$ values (Moorthy et al., 2009). It should be noted that the derived aerosol properties (SAE, AAE, SSA) were calculated for the whole dataset of the hourly $b_{\text {sca }}$ and $b_{\text {abs }}$ values, since the latter are high enough $\left(>0.8-1.0 \mathrm{Mm}^{-1}\right)$ in order to provide estimations with limited uncertainties (Ealo et al., 2018; Pandolfi et al., 2018).

\section{Chemical Reconstruction of Scattering}

The reconstruction of the aerosol $b_{\text {sca }}$ is performed via the formula proposed by Sciare et al. (2005), using the ACSM measurements on a daily basis:

$\mathrm{b}_{\mathrm{sca}}=\alpha_{\mathrm{AS}}[\mathrm{AS}] f(\mathrm{RH})+\alpha_{\mathrm{POM}}[\mathrm{POM}]$

where $\alpha_{\mathrm{AS}}$ is the mass scattering efficiency (MSE) of ammonium sulfate (AS: $\left.\left(\mathrm{NH}_{4}\right)_{2} \mathrm{SO}_{4}\right)$ and [AS] its mass concentration. $f(\mathrm{RH})$ is an empirical factor, i.e., the lightscattering enhancement factor that depends on $\mathrm{RH}$, while $\alpha_{\mathrm{POM}}$ and [POM] are the MSE and mass concentration of particulate organic matter (POM), respectively. However, considering the presence of ammonium nitrate (AN: $\mathrm{NH}_{4} \mathrm{NO}_{3}$ ) during wintertime, the formula is adjusted as follows:

$\mathrm{b}_{\mathrm{sca}}=\alpha_{\mathrm{AS}}[\mathrm{AS}] f(\mathrm{RH})+\alpha_{\mathrm{AN}}[\mathrm{AN}] f(\mathrm{RH})+\alpha_{\mathrm{POM}}[\mathrm{POM}]$

where $\alpha_{\mathrm{AN}}$ and $[\mathrm{AN}]$ are the respective MSE and mass 
concentration of ammonium nitrate. As the $\mathrm{RH}$ in the Nephelometer was kept below $40 \%$, the measuring conditions are considered as dry and, therefore, $f(\mathrm{RH})=1$ in Eqs. (4) and (5), indicating no light-scattering enhancement due to aerosol water uptake under humid conditions.

For the $b_{\text {sca }}$ reconstruction, the values of $2.69 \mathrm{~m}^{2} \mathrm{~g}^{-1}$ for the $\alpha_{\mathrm{AS}}$ and $4.6 \mathrm{~m}^{2} \mathrm{~g}^{-1}$ for the $\alpha_{\mathrm{POM}}$ were used, as calculated from long-term measurements in Athens at $550 \mathrm{~nm}$ (August 2010-April 2013; Paraskevopoulou, 2014). These values are in accordance with MSE values of 2.66 and $4.19 \mathrm{~m}^{2} \mathrm{~g}^{-1}$ for $\alpha_{\mathrm{AS}}$ and $\alpha_{\mathrm{POM}}$, respectively, derived by Sciare et al. (2005) for the remote background site of Finokalia. The respective value for $\alpha_{\mathrm{AN}}$ was taken as $2.7 \mathrm{~m}^{2} \mathrm{~g}^{-1}$ from the reported global average. The MSE values for both AS and AN are in accordance with the average of $2.9 \pm 0.3 \mathrm{~m}^{2} \mathrm{~g}^{-1}$ (range from 2.0 to $3.4 \mathrm{~m}^{2} \mathrm{~g}^{-1}$ ) reported for $\alpha_{\text {inorg }}$ at 38 sites around the US (Malm and Hand, 2007). As MSE for POM might be site specific with respect to the sources and loadings, the current $\alpha_{\mathrm{POM}}$ of $4.6 \mathrm{~m}^{2} \mathrm{~g}^{-1}$ is in accordance with the value of $3.81 \mathrm{~m}^{2} \mathrm{~g}^{-1}$ derived by Malm and Hand (2007), based on prorating the AS mass scattering efficiency by the ratio of AS and POM densities. The $\alpha$ POM in our case is also comparable to $4.5 \pm 0.73 \mathrm{~m}^{2} \mathrm{~g}^{-1}$, reported by Cheng et al. (2015) for polluted environment in China, while an MSE value of $3.6 \mathrm{~m}^{2} \mathrm{~g}^{-1}$ is reported by Ealo et al. (2018) for aged organics.

\section{RESULTS AND DISCUSSIONS}

\section{Aerosol Scattering and Absorption Coefficients}

This section analyzes the temporal variability of the aerosol $b_{\text {sca }}$ and $b_{a b s}$ values as a function of their wavelength dependence, wind speed, boundary-layer dynamics and emission sources. The monthly variation of the spectral $b_{\text {sca }}$ and $b_{a b s}$ in box-whisker charts is shown in Figs. 1(a) and $1(b)$, respectively. The average $b_{\text {sca }}$ and $b_{a b s}$ values during the whole study period were $46.0 \pm 32.2 \mathrm{Mm}^{-1}$ and $28.4 \pm$ $36.3 \mathrm{Mm}^{-1}$, at the central wavelengths of 550 and $520 \mathrm{~nm}$,
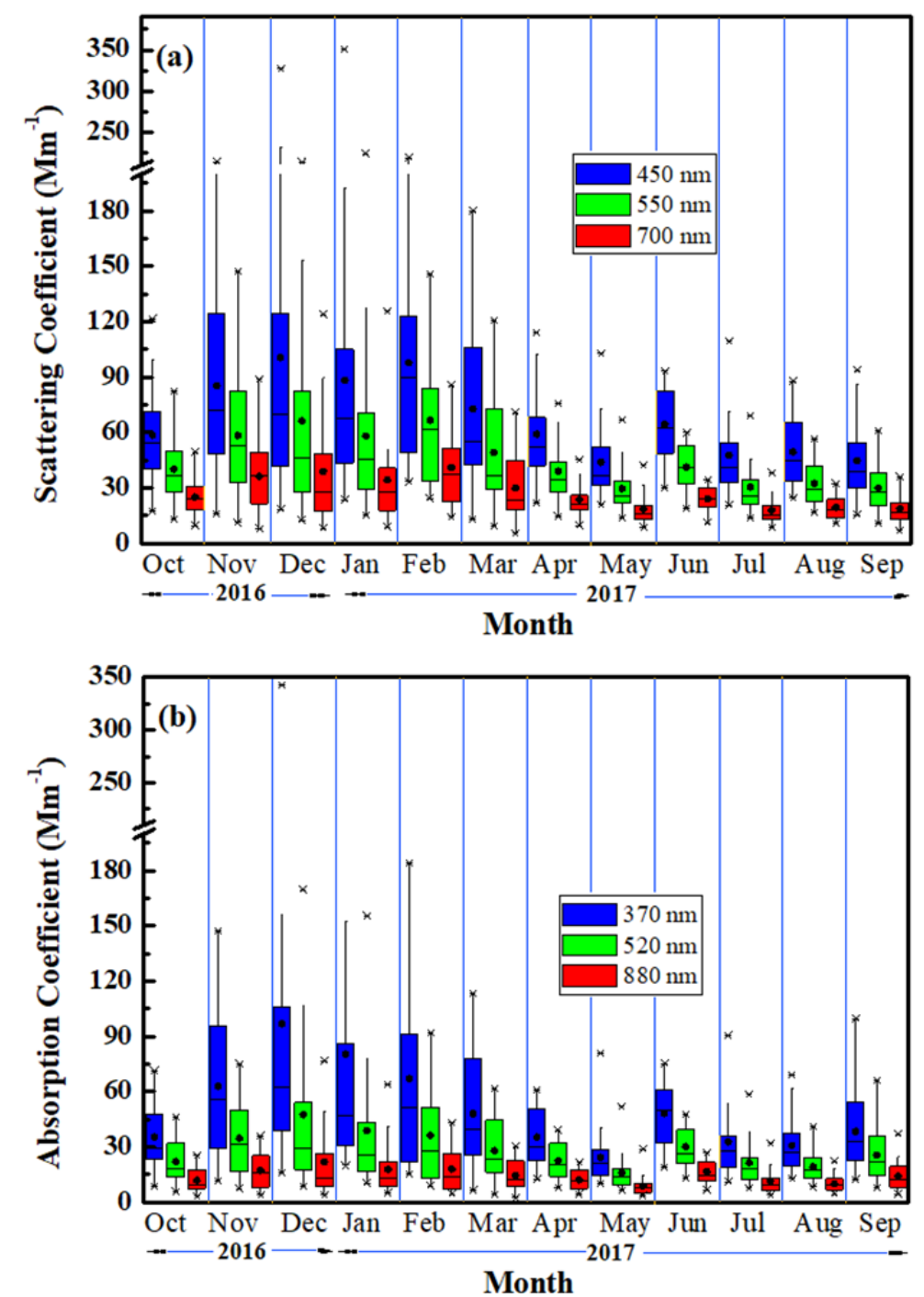

Fig. 1. Monthly values of the spectral (a) $b_{\text {sca }}$ and (b) $b_{a b s}$ over Athens from October 2016 to September 2017. The box's upper and lower limits are the 75 and 25 percentiles, respectively, the black circle corresponds to the mean and the straight line denotes the median. The whiskers denote the 95 and 5 percentiles. 
respectively (Table 1). In all months, the means are larger than the respective medians, indicating a tail towards large values of scattering and absorption (positive skewness), reflecting the episodic nature of high values, as also found at several European sites (Pandolfi et al., 2018). The $b_{\text {sca }}$ monthly means maximize in December and February (66.3 and $66.6 \mathrm{Mm}^{-1}$ at $550 \mathrm{~nm}$, respectively), while low plateau values are observed in the warm period (May-September, $30-35 \mathrm{Mm}^{-1}$ at $550 \mathrm{~nm}$ ). In general, the monthly variation exhibits the same pattern regardless of the wavelength, but as the wavelength decreases the $b_{\text {sca }}$ values and the corresponding ranges increase significantly due to higher sensitivity of scattering at shorter wavelengths (Fig. 1(a)). The larger range in the $b_{\text {sca }}$ values from November to February indicates large variability in the local emission rates and in aerosol concentrations near the surface, while during spring and summer less variability exists, indicative of mostly regional-background conditions. A similar annual pattern is shown for the spectral $b_{a b s}$ that maximizes in December (mean of $47.8 \mathrm{Mm}^{-1}$ at $520 \mathrm{~nm}$ ) and presents lowest values in May (mean of $15.9 \mathrm{Mm}^{-1}$ at $520 \mathrm{~nm}$ ) (Fig. 1(b)). The remarkable monthly variability at $370 \mathrm{~nm}$ (means ranging from $24.2 \mathrm{Mm}^{-1}$ to $97.8 \mathrm{Mm}^{-1}$ ) is highly weakened at $880 \mathrm{~nm}$ (means from 8.7 to $22.0 \mathrm{Mm}^{-1}$ ), indicative of large fraction and strong seasonality of the UV-absorbing aerosols. The large range in the winter months indicates local aerosol emissions from various sources with large fluctuation in the emission rates and/or influences from meteorology. Similar to our results, several urban and regional sites in Europe (Alsaaideh et al., 2017) exhibited higher $b_{\text {sca }}$ and $b_{a b s}$ values in winter compared to summer, due to lower dispersion, stagnant air masses and low-level temperature inversions (Putaud et al., 2014; Pandolfi et al., 2018).

The $b_{\text {sca }}$ values at the urban/background site of Thissio are, in general, higher than most of those reported for 25 sites all around Europe, since only 6 stations exhibited higher values (Pandofli et al., 2018). Titos et al. (2014) reported $b_{\text {sca }}$ values of $41 \pm 34 \mathrm{Mm}^{-1}$ for winter 2013 and $38 \pm 26$ $\mathrm{Mm}^{-1}$ for spring 2013 in Granada, Spain, which are similar in spring, but much lower in winter compared to Athens. However, much lower $b_{a b s}$ values were found in Granada $\left(17 \mathrm{Mm}^{-1}\right.$ and $11 \mathrm{Mm}^{-1}$ for winter 2013 and spring 2013, respectively; Titos et al., 2014) compared to Athens. The $b_{\text {sca }}$ values in Athens are comparable in magnitude, although slightly lower, to those found for clean and heavy smog days (26 Mm $\mathrm{Mm}^{-1}$ and $410 \mathrm{Mm}^{-1}$, respectively) in Los Angeles (Seinfeld and Pandis, 1998). In contrast, very high values of $b_{\text {sca }}\left(230-700 \mathrm{Mm}^{-1}\right)$ and $b_{a b s}\left(60-80 \mathrm{Mm}^{-1}\right)$ were reported over highly-polluted megacities like Beijing (He et al., 2009), New Delhi (Dumka et al., 2017) and Mexico City (Paredes-Miranda et al., 2009).

Figs. 2(a)-2(b) show the daily variability of the $b_{\text {sca }}$ (from 9.2 to $223.9 \mathrm{Mm}^{-1}$ ) and $\mathrm{b}_{\mathrm{abs}}\left(4.3\right.$ to $169.7 \mathrm{Mm}^{-1}$ ) as a function of the $\mathrm{SAE}_{450-700}$ and $\mathrm{AAE}_{370-880}$ values, respectively (colored scales), while hourly $b_{\text {sca }}$ and $b_{a b s}$ values as high as $\sim 700 \mathrm{Mm}^{-1}$ and $\sim 500 \mathrm{Mm}^{-1}$, respectively, were recorded during pollution-smog conditions. Enhanced daily $b_{\text {sca }}$ values are encountered from December to February exhibiting a decreasing tendency afterwards (Fig. 2(a)), while the $b_{a b s}$ follows a similar fluctuation (Fig. 2(b)). The scatter plot between the hourly $b_{\text {sca }}$ and $b_{\text {abs }}$ values (Suppl. Fig. S1) exhibited a significant correlation (slope $=0.72 ; \mathrm{R}^{2}=0.80$, $\mathrm{N}=7758$ ), indicating a covariance in the scattering and absorption aerosol properties due to similarity in the emission sources. During December-January a more homogeneous atmosphere, composed by fine-mode anthropogenic aerosols $(\mathrm{SAE}>2.0)$ is the dominant scenario, contrary to the transition months (March-May and September-November), which show important heterogeneity in the aerosol sources and properties. Remarkable seasonality is observed in AAE with large $(>1.5)$ values even for low $b_{a b s}$ in December and January, and values mostly below $\sim 1.4$ from April to October (Fig. 2(b)). The numerous forest fires in Greece during summer 2017 do not seem to influence the aerosol loading $\left(b_{\text {sca }}, b_{a b s}\right)$ in Athens center, since the transported smoke plumes were traversed at elevated heights far away from the Attica region.

However, in this work, emphasis is given on examining the extensive and intensive aerosol properties of urban/anthropogenic aerosols during dry conditions. In this respect, the rainy days, based on data from the NOA's meteorological station at Thissio, were excluded from the rest of the analysis, as well as the dusty days. The dusty days were flagged based initially on HYSPLIT back trajectories for the major dust storms affecting the eastern Mediterranean and Greece, combined with concurrent sharp peaks in the measured $\mathrm{PM}_{10}$ concentrations

Table 1. Mean values of the aerosol optical properties in Athens for the whole dataset and after excluding the dusty and rainy days (in parenthesis).

\begin{tabular}{llllll}
\hline & Whole period & Winter & Spring & Summer & Autumn \\
\hline $\mathrm{b}_{\text {sca }}$ & $46.01 \pm 32.21$ & $63.57 \pm 73.59$ & $39.26 \pm 29.55$ & $33.50 \pm 15.63$ & $42.77 \pm 34.45$ \\
$(550 \mathrm{~nm})$ & $(47.19 \pm 48.90)$ & $(72.81 \pm 81.14)$ & $(40.27 \pm 29.94)$ & $(33.64 \pm 14.70)$ & $(41.23 \pm 31.89)$ \\
$\mathrm{b}_{\mathrm{abs}}$ & $28.45 \pm 36.29$ & $41.01 \pm 59.72$ & $22.04 \pm 21.68$ & $22.95 \pm 18.04$ & $27.61 \pm 28.17$ \\
$(520 \mathrm{~nm})$ & $(29.14 \pm 39.18)$ & $(45.70 \pm 65.92)$ & $(23.25 \pm 22.39)$ & $(20.58 \pm 13.53)$ & $(26.45 \pm 27.47)$ \\
$\mathrm{SAE}$ & $1.99 \pm 0.34$ & $1.99 \pm 0.34$ & $1.98 \pm 0.35$ & $2.14 \pm 0.23$ & $1.89 \pm 0.39$ \\
$(450-700)$ & $(2.02 \pm 0.31)$ & $(2.05 \pm 0.21)$ & $(2.02 \pm 0.27)$ & $(2.14 \pm 0.24)$ & $(1.89 \pm 0.35)$ \\
$\mathrm{AAE}$ & $1.32 \pm 0.23$ & $1.50 \pm 0.26$ & $1.25 \pm 0.16$ & $1.24 \pm 0.18$ & $1.28 \pm 0.18$ \\
$(370-880)$ & $(1.33 \pm 0.22)$ & $(1.53 \pm 0.26)$ & $(1.26 \pm 0.15)$ & $(1.25 \pm 0.15)$ & $(1.28 \pm 0.18)$ \\
$\mathrm{SSA}$ & $0.62 \pm 0.11$ & $0.60 \pm 0.08$ & $0.64 \pm 0.12$ & $0.61 \pm 0.09$ & $0.61 \pm 0.12$ \\
$(550 \mathrm{~nm})$ & $(0.66 \pm 0.11)$ & $(0.68 \pm 0.08)$ & $(0.67 \pm 0.13)$ & $(0.65 \pm 0.08)$ & $(0.61 \pm 0.13)$ \\
\hline
\end{tabular}



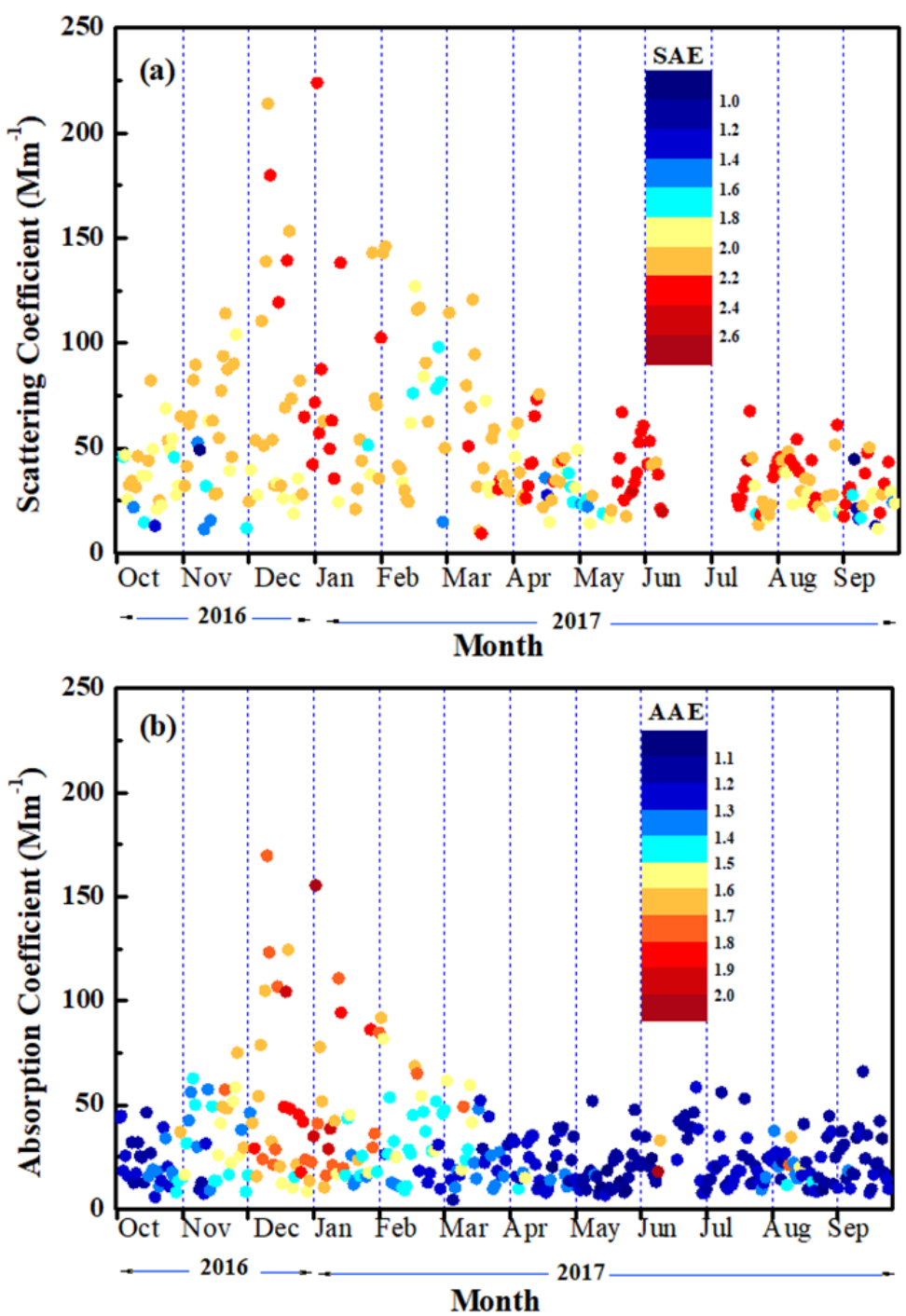

Fig. 2. Temporal variation of the daily values of (a) $b_{\text {sca }}$ at $550 \mathrm{~nm}$ and (b) $b_{a b s}$ at $520 \mathrm{~nm}$ during the whole period as a function of the daily $\mathrm{SAE}_{450-700}$ and $\mathrm{AAE}_{370-880}$ values (colored scales), respectively.

(Diapouli et al., 2017b). Overall, 271 days with 6269 hourly data remained for the analysis (1489 hours were excluded). The main aerosol optical properties (e.g., $b_{\text {sca }}$, $\mathrm{b}_{\mathrm{abs}}$, SAE, AAE, SSA) present marginal differences in the case of exclusion of the dusty and rainy days, as can be seen from Table 1. However, this exclusion leads to higher $b_{\text {sca }}$ and $b_{\text {abs }}$ values, as well as to differences between the two datasets in winter due to much lower concentrations on the rainy days (washout). Furthermore, the hourly datasets for all aerosol properties were classified into two groups based on the hourly WS threshold of $3 \mathrm{~m} \mathrm{~s}^{-1}$, which was identified as a critical value for the discrimination between high-to-very high and moderate-to-low $\mathrm{b}_{\mathrm{sca}}$ and $\mathrm{b}_{\mathrm{abs}}$ values (see Suppl. Fig. S2). That figure shows that both $b_{\text {sca }}$ and $b_{a b s}$ values exhibited a rather exponential increase for WS below $3 \mathrm{~m} \mathrm{~s}^{-1}$. Furthermore, there is greater possibility for enhanced AAE values for WS $<3 \mathrm{~m} \mathrm{~s}^{-1}$, probably attributed to the influence of residential wood burning in winter nights under weak-to-calm winds (see Suppl. Fig. S3). The cases with WS $<3 \mathrm{~m} \mathrm{~s}^{-1}$ are characterized as haze/smog conditions and the other as non-smog, following the classification by Fourtziou et al. (2017). Therefore, the rest of the study focuses on analyzing the near-surface urban/anthropogenic aerosols, and separately for the smog and non-smog conditions on a seasonal basis, in order to reveal changes in aerosol properties attributed to different sources, meteorology and wind speed.

The seasonally-averaged diurnal cycles of the $b_{\text {sca }}$ (Figs. 3(a)-3(d)) and babs (Figs. 4(a)-4(d)) are examined separately for the two groups, i.e., $\operatorname{smog}\left(\mathrm{WS}<3 \mathrm{~m} \mathrm{~s}^{-1}\right.$ ) and non-smog (WS $\geq 3 \mathrm{~m} \mathrm{~s}^{-1}$ ) conditions, revealing a remarkable, seasonally-changed, and wind dependent diurnal variability. Very high seasonal-mean $b_{\text {sca }}$ values (at $450 \mathrm{~nm}$ ) reaching $250-300 \mathrm{Mm}^{-1}$ are recorded during the night hours in winter for $\mathrm{WS}<3 \mathrm{~m} \mathrm{~s}^{-1}$, indicating significant accumulation of aerosols and pollutants near the surface and formation of haze/smog conditions. In contrast, the cases with WS $\geq 3 \mathrm{~m} \mathrm{~s}^{-1}$ are characterized by much lower $b_{\text {sca }}$ values, especially during nighttime, indicating rather efficient dispersion of aerosols. A secondary $b_{\text {sca }}$ peak 

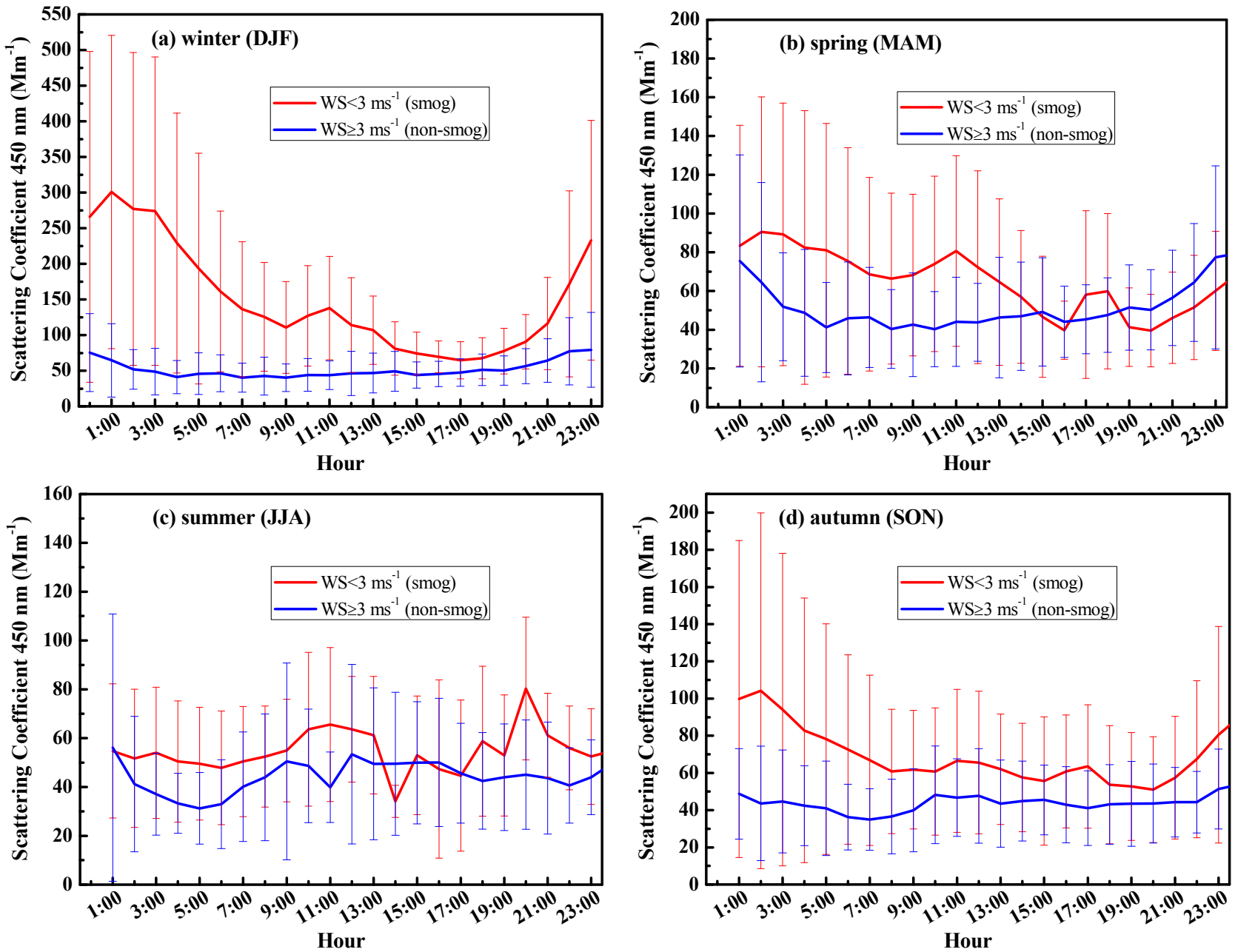

Fig. 3. Seasonal-mean diurnal patterns of $b_{\text {sca }}(450 \mathrm{~nm})$ for cases with wind speeds above and below $3 \mathrm{~m} \mathrm{~s}^{-1}$. The rainy and dusty days have been excluded. The vertical bars correspond to one standard deviation from the hourly mean.

around 11:00 LST is shown in winter that is absent under WS $\geq 3 \mathrm{~m} \mathrm{~s}^{-1}$ conditions, which is attributed to the morning traffic rush hour, usually peaking 1-2 hours earlier. This suggests that the urban emissions need about 1-2 hours, depending on the general flow within the basin, to reach the urban/background site of Thissio (at the top of the hill of Nymphs). After this slight morning peak, the $b_{\text {sca }}$ levels are progressively decreasing till about 16:00-17:00 LST due to increase in the mixing-layer height (MLH) and the higher vertical and horizontal dispersion (Kalogridis et al., 2018). The lowest $b_{\text {sca }}$ levels of $\sim 70 \mathrm{Mm}^{-1}$ at 17:00 LST increase abruptly ( $\sim 3 \mathrm{Mm}^{-1}$ per hour) till about 00:0001:00, due to enhanced emissions mostly from bio-fuel and residential wood burning for heating purposes (Panopoulou et al., 2017; Kalogridis et al., 2018). On this increase, the evening traffic-rush hours and the fossil-fuel emissions from the central heating should not be ignored, but previous studies at Thissio clearly revealed that the largest amounts of $\mathrm{OC}, \mathrm{BC}$ and $\mathrm{CO}$ emissions during winter nighttime come from wood burning (Fourtziou et al., 2017; Gratsea et al., 2017; Stavroulas et al., 2018). The fading use of fire places till about 11:00-00:00 LST and the near absence of traffic during nighttime contribute to the progressive decrease of the $b_{\text {sca }}$ levels during the night. On the contrary, the $b_{\text {sca }}$ values are much lower during the other seasons and for the non-smog cases, suggesting more transparent atmospheric conditions, on which the locally-emitted aerosols have less impact on the near-surface concentrations. Furthermore, the diurnal variations of the $b_{\text {sca }}$ seem to be nearly independent from the WS in the other seasons, except for the night hours in spring and autumn due to accumulation of aerosols in the cold months of March and November, respectively.

In general, the seasonal-mean diurnal cycles of $b_{a b s}$ (Figs. 4(a)-4(b)) follow those of $b_{\text {sca }}$ (Figs. 3(a)-3(d)). Therefore, during winter, $b_{a b s}$ exhibits a pronounced peak at 10:00-11:00 LST (1-2 hours after the morning rush traffic), indicating the presence of highly-absorbing aerosols from vehicle exhaust (cases with $\mathrm{WS}<3 \mathrm{~m} \mathrm{~s}^{-1}$ ). However, the primary peak in $b_{a b s}\left(170-180 \mathrm{Mm}^{-1}\right.$ at $\left.470 \mathrm{~nm}\right)$ is observed during late night (23:00-01:00 LST), due to higher relative contribution by wood burning and OC emissions for heating purposes (Fourtziou et al., 2017; Gratsea et al., 2017), as also shown in Paris (Sciare et al., 2011); Ispra, Italy (Putaud et al., 2014); Barcelona, Spain (Minguillón et al., 2015), and in Alpine sites in Switzerland (Zotter et al., 2017). This is especially pronounced for the low-wind cases 

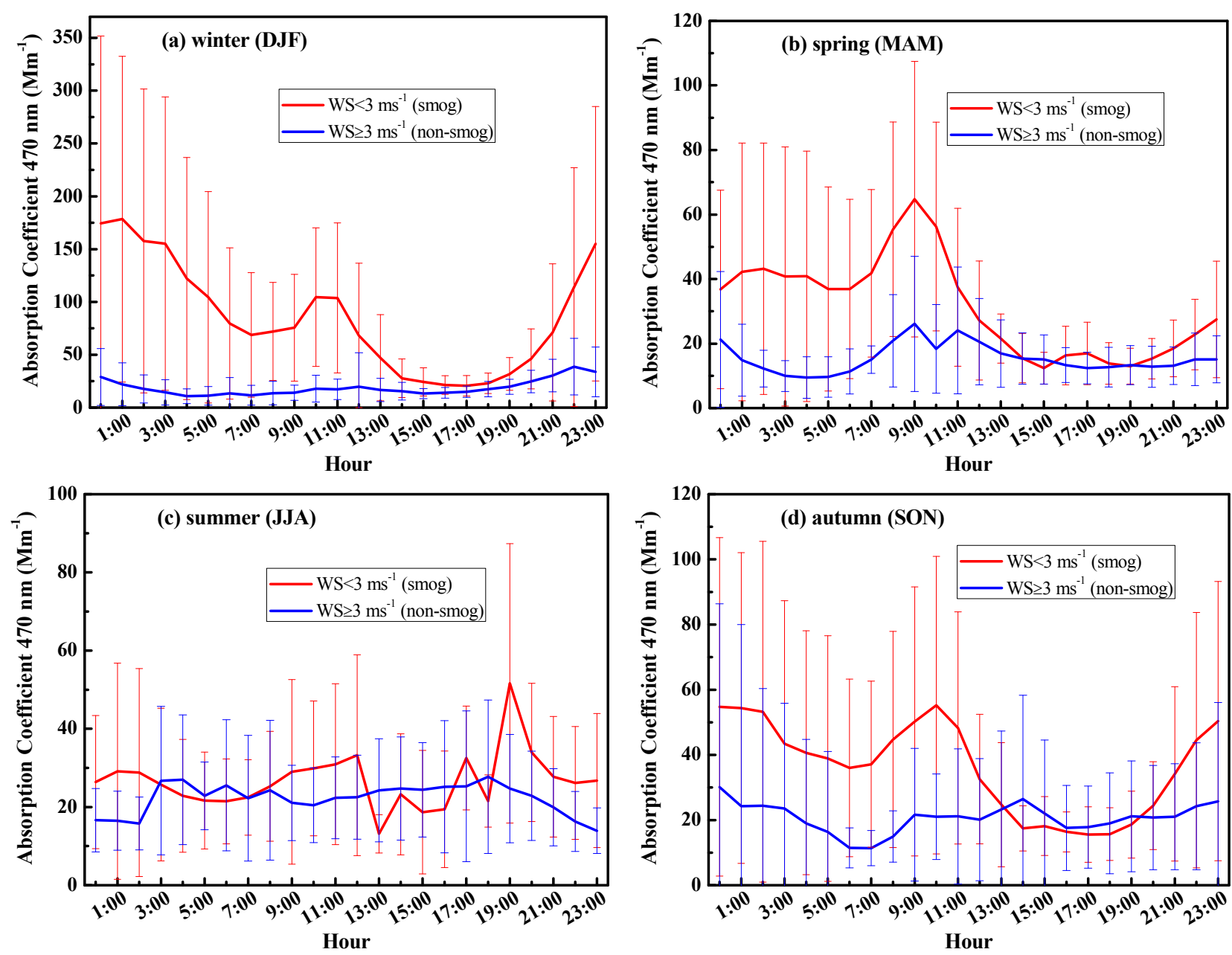

Fig. 4. Seasonal-mean diurnal patterns of the $b_{\text {abs }}(470 \mathrm{~nm})$ for cases with wind speeds above and below $3 \mathrm{~m} \mathrm{~s}^{-1}$. The rainy and dusty days have been excluded. The vertical bars correspond to one standard deviation from the hourly mean.

indicating a highly-absorbing aerosol laden atmosphere in Athens center, while the diurnal patterns of $b_{a b s}$ exhibit much lower variability in the other seasons. The local, freshly emitted aerosols from traffic seem to affect more the light absorption rather than scattering, since the morning peaks in $b_{a b s}$ are more pronounced than those for $b_{\text {sca }}$. In autumn (Fig. 4(d)), the morning and night peaks are equal, while in spring (Fig. 4(b)) the morning traffic exhibits a higher signal in $b_{a b s}$; in contrast, both diurnal patterns flatten out in summer (Fig. 4(c)). Similar to $b_{\text {sca, }}$ any diurnal cycle nearly vanishes in the non-smog cases (WS $\geq 3 \mathrm{~m} \mathrm{~s}^{-1}$ ), except of the slight increase during the morning hours in spring, indicating a good mixing and dispersion of pollutants under higher wind speeds.

The regionally-changing daily wind patterns and the local sea-land breeze circulation may also affect the diurnal patterns of $b_{\text {sca }}$ and $b_{a b s}$, resulting in large standard deviations from the respective means. As the industrial and vehicular emissions within the Athens Basin are assumed nearly constant during daytime, the large decrease in the $b_{\text {sca }}$ and $b_{a b s}$ at noon and early afternoon is attributed to boundarylayer dynamics, i.e., deepening of the MLH due to solar heating that favors the vertical and horizontal dispersion of the aerosols and pollutants (Cohen and Wang, 2014; Lee et al., 2016). Previous studies (Grivas et al., 2008; Gratsea et al., 2017) have also shown increased PM concentrations over Athens during the early morning and evening hours due to lower MLH and trapping of pollutants near the ground, followed by lower concentrations around noon. Therefore, the boundary-layer dynamics and the dispersion processes play an important role in the prevention of pollutant accumulation, in redistribution of aerosols and in weakening of the impact of local sources.

The $b_{\text {sca }}$ and $b_{a b s}$ coefficients are further examined against $\mathrm{PM}_{2.5}, \mathrm{PM}_{10}$ concentrations and gaseous pollutants (CO and NO), characteristic for traffic-related and biomassburning emissions. December 2016 was chosen for this analysis due to its high aerosol concentrations (Figs. 1(a)1(b)). The diurnal cycles of scattering at $550 \mathrm{~nm}, \mathrm{CO}, \mathrm{NO}$ and $\mathrm{PM}_{10}$ concentrations show, in general, great similarities driven by the changes in the emission sources and MLH (Fig. 5). Therefore, as in the $b_{\text {sca }}$ case, two maxima exist for both $\mathrm{CO}$ and $\mathrm{NO}$, but with a characteristic time shift in the evening hours and a difference between the primary and secondary peaks. $\mathrm{CO}$ presents a better coincidence with $b_{\text {sca }}$, peaking at 23:00 LST due to enhanced emissions 


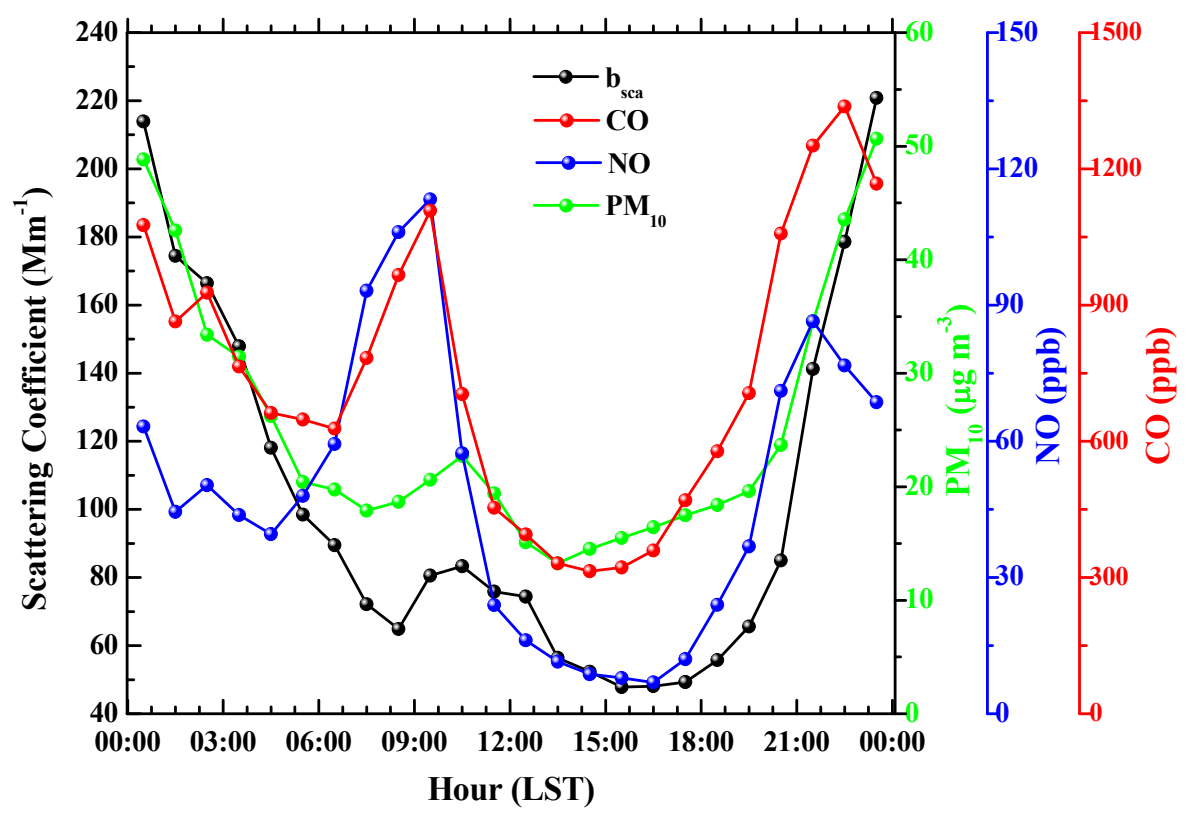

Fig. 5. Mean diurnal variations for the $b_{\text {sca }}(550 \mathrm{~nm}), \mathrm{CO}, \mathrm{NO}$ and $\mathrm{PM}_{10}$ over Athens in December 2016.

from heating sources, while the secondary peak at $\sim 09: 00$ LST is related to the morning rush traffic (fossil-fuel emissions) and coincides with NO. During the evening-tonight hours, NO peaks one hour before $\mathrm{CO}$, coinciding with the evening rush traffic, while $\mathrm{CO}$ is mostly related to wood burning (Koyuncu and Pinar, 2007). However, the morning $b_{\text {sca }}$ secondary peak is not so remarkable, revealing much less aerosol abundance or even fewer scattering particles during the morning traffic hours. Note also the excellent coincidence between $\mathrm{b}_{\text {sca }}$ and $\mathrm{PM}_{10}$ diurnal patterns in December $\left(\mathrm{R}^{2}=0.95\right)$, revealing that the primary gas emissions during the morning hours do not impose a distinct signal on $\mathrm{PM}_{10}$ concentrations, whereas the wood burning emissions contribute significantly to the increased $\mathrm{PM}_{10}$ levels (above $40 \mathrm{\mu} \mathrm{m}^{-3}$ ) during nighttime. The correlation of $b_{\text {sca }}$ with $\mathrm{CO}$ and NO in December was of $\mathrm{R}^{2}=0.73$ (slope: 4.94 ) and $\mathrm{R}^{2}=0.14$ (slope: 0.23 ), respectively. In addition, a strong correlation $\left(\mathrm{R}^{2}=0.80\right.$, slope: 0.28$)$ was found between the daily $\mathrm{b}_{\text {sca }}$ and $\mathrm{PM}_{2.5}$ concentrations during the whole period, which is similar to that reported in Ispra, north Italy $\left(\mathrm{R}^{2}=0.87\right)$, between dry $\mathrm{PM}_{2.5}$ and scattering coefficient (Putaud et al., 2014). Very good correlations between $b_{\text {sca }}$ and $\mathrm{PM}_{1}$ concentrations, with $\mathrm{R}^{2}$ values of $0.86-0.89$, were also reported in a regional site in NE Spain (Pandolfi et al., 2011).

The diurnal cycles of $b_{a b s}, C O$ and NO in December (Fig. 6) are almost identical, highlighting the vital role of the primary combustion sources on the aerosol absorption processes. Therefore, apart from the evening/night peaks in $\mathrm{CO}$ and $\mathrm{NO}$, associated with the wood burning and evening traffic hours, as discussed above, the morning gaseous peaks due to traffic have a direct effect on aerosol absorption, contrary to that found for scattering. This suggests significant amounts of freshly-emitted $\mathrm{BC}$ aerosols with high absorbing capability. Furthermore, the $\mathrm{CO} / \mathrm{NO}$ ratio may be used for qualitative assessment of the relative dominance between traffic and biomass burning (Sandradewi et al., 2008; Sciare et al., 2011). Wood burning leads to higher CO emissions, while fossil-fuel combustion in vehicle engines occurs at high temperatures, is more complete, with higher NO emissions and lower $\mathrm{CO} / \mathrm{NO}$ ratios (Koyuncu and Pinar, 2007; Reche et al., 2012). Therefore, the lower CO/NO values are observed during the morning (around 8:00-9:00 LST) and evening (around 20:00-21:00 LST) rush traffic hours, whereas during nighttime the $\mathrm{CO} / \mathrm{NO}$ ratio slightly increases reflecting the wood burning. The average diurnal pattern of $\mathrm{CO} / \mathrm{NO}$ in December ranges between 8.4 and 52.2 with a mean of $20.8 \pm 10.8$, suggesting remarkable variability in the anthropogenic and natural emissions, combustion sources and changes in the relative dominance between them within the urban environment (Reche et al., 2012; Zheng et al., 2017). However, during daytime, the NO concentrations are also affected by the oxidation of $\mathrm{NO}$ to $\mathrm{NO}_{2}$, while the photochemical reactions reduce the $\mathrm{NO}$ in much higher rate than $\mathrm{CO}$, resulting in larger $\mathrm{CO} / \mathrm{NO}$ values during noontime (Fig. 6). In addition, $\mathrm{CO} / \mathrm{NO}$ ratio might change due to aging processes, even without changes in the emission sources, since $\mathrm{CO} / \mathrm{NO}$ increases for aged aerosols due to lower lifetime of $\mathrm{NO}$ compared to $\mathrm{CO}$ (Sandradewi et al., 2008).

\section{$S A E$ and $A A E$}

The monthly variations of the $\mathrm{SAE}$ values at three wavelength bands (450/550, 450/700, 550/700 nm), and AAE at the $370-520 \mathrm{~nm}, 370-880 \mathrm{~nm}$, and $520-880 \mathrm{~nm}$ are examined in Figs. 7(a)-7(b). Despite the wide range in SAE values (from below 1.0 to 2.6), the monthly means and medians lie between $\sim 1.9$ and 2.2 (Fig. 7(a)), suggesting a clear dominance of fine urban/anthropogenic aerosols (Srivastava et al., 2014). The much lower range in SAE values in June may be attributed to a smaller dataset in this month (202 hours, instead of e.g., 504 in May). The annual 


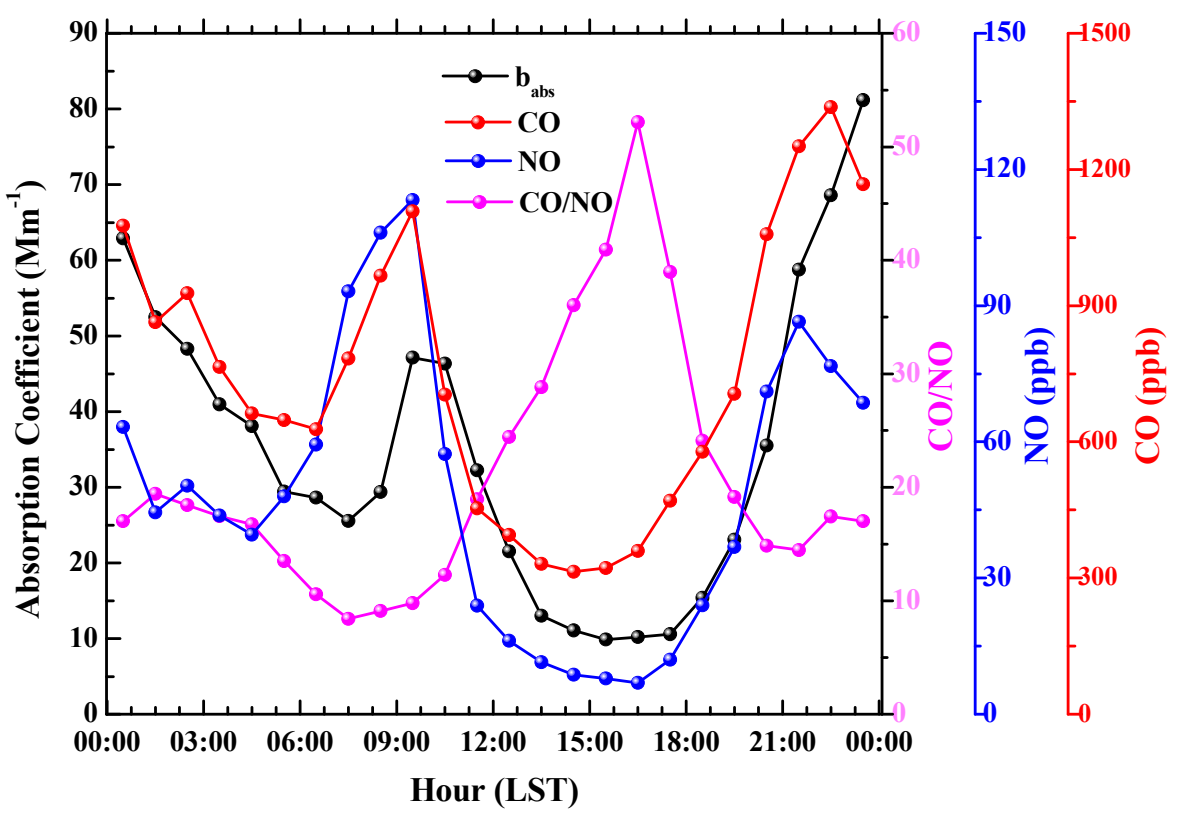

Fig. 6. Mean diurnal variations for the $b_{a b s}(880 \mathrm{~nm}), \mathrm{CO}, \mathrm{NO}$ and CO/NO ratio over Athens in December 2016.

averages for $\mathrm{SAE}_{450-550}, \mathrm{SAE}_{450-700}$ and $\mathrm{SAE}_{550-700}$ values are very close to each other, $1.99 \pm 0.29,2.02 \pm 0.31$ and $2.03 \pm 0.34$, respectively. The SAE values increase with wavelength (i.e., $\mathrm{SAE}_{550-700}>\mathrm{SAE}_{450-550}$ ) from October to March, whereas they present a neutral to declining tendency from April to September (except from June). This indicates some differences in the fine-to-coarse mode aerosol ratio, since the increase in SAE with the wavelength implies larger fraction of fine-mode aerosols (larger fineto-coarse mode ratio) during the winter months, while neutral to slightly decreasing values indicate a rather good mixing of fine and coarse particles (Eck et al., 2005; Schuster et al., 2006). Large SAE values (>2.0) are observed in summer (Fig. 7(a)), mostly representing regional background conditions and secondary organic aerosol (SOA) formation in the absence of dust near the surface. Note that carbonaceous aerosols were also responsible for the high SAE values $(\sim 2.2-2.4)$ in summer in NE Spain (Ealo et al., 2018). High SAE values $(\sim 1.8-2.0)$ were also reported at other central and eastern European sites, which maximized in summer due to higher biogenic SOA and new-particle formation, while they could be considered as typical for background conditions of no-dust (Ma et al., 2014; Pandolfi et al., 2018).

On the other hand, the large monthly variation in the AAE values and wavelength dependence (Fig. 7(b)) suggests remarkable changes in the dominant aerosol types and emission sources. Therefore, the larger $\mathrm{AAE}_{370-520}$ values and wavelength dependence of AAE are associated with enhanced contribution from biomass-burning aerosols (November-March), while values of AAE close to 1.1-1.2 with less wavelength dependence correspond to a clear dominance of fossil-fuel (vehicles, industries) combustion in spring and summer (Kirchstetter et al., 2004; Andreae and Gelencsér, 2006; Zotter et al., 2017). The AAE values are significantly lower as the wavelength increases implying much lesser impact of wood burning emissions (Sandradewi et al., 2008; Titos et al., 2017). The slightly larger AAE values in August are attributed to the influence of forest fires (13-15 August 2017) about $40 \mathrm{~km}$ northeast of Athens. During the whole period, the $\mathrm{AAE}_{370-880}$ ranges from 1.1 to 2.1 on a daily basis, with an average of $1.33 \pm 0.22$. Very different AAE values are reported in the literature depending on the fuel type and combustion efficiency (flaming or smoldering), such as values of $\sim 2.2$ for firewood burning, $\sim 1.8$ for savanna fires and $0.8-1.1$ for traffic (Eck et al., 2003; Kirchstetter et al., 2004; Day et al., 2006).

The seasonal-mean diurnal variations of $\mathrm{SAE}_{450-700}$ for WS above and below $3 \mathrm{~m} \mathrm{~s}^{-1}$ do not exhibit distinct patterns in any season and/or for the separate data groups (Fig. 8). Therefore, no important diurnal cycles regarding changes in the particle size or in the fine-to-coarse mode aerosol ratios could be extracted and an overall dominance of fine-mode anthropogenic aerosols is revealed. However, in winter and autumn, the SAE values for the smog cases are slightly higher throughout the day, indicating enhanced presence of fine, freshly-emitted aerosols. The seasonalmean diurnal patterns of AAE (Fig. 9) clarify the dominance of different aerosol sources and combustion processes in the Athens Basin according to season and hour of the day. Therefore, local emissions from bio-fuel burning dominate in the evening and night hours in winter (large AAE values) and presence of aerosols from fossil-fuel combustion, or $\mathrm{SOA}$ formation (low values of AAE), dominate around noon in winter and in the other seasons (Bergstrom et al., 2007).

Relating SAE to AAE values is able to reveal aerosol types of different origin and combustion sources, since concurrently high AAE and SAE correspond to biomassburning aerosols, while low SAE and high AAE values are indicative of desert dust; values of AAE around 1.0-1.1 associated with high SAE imply for urban emissions from 

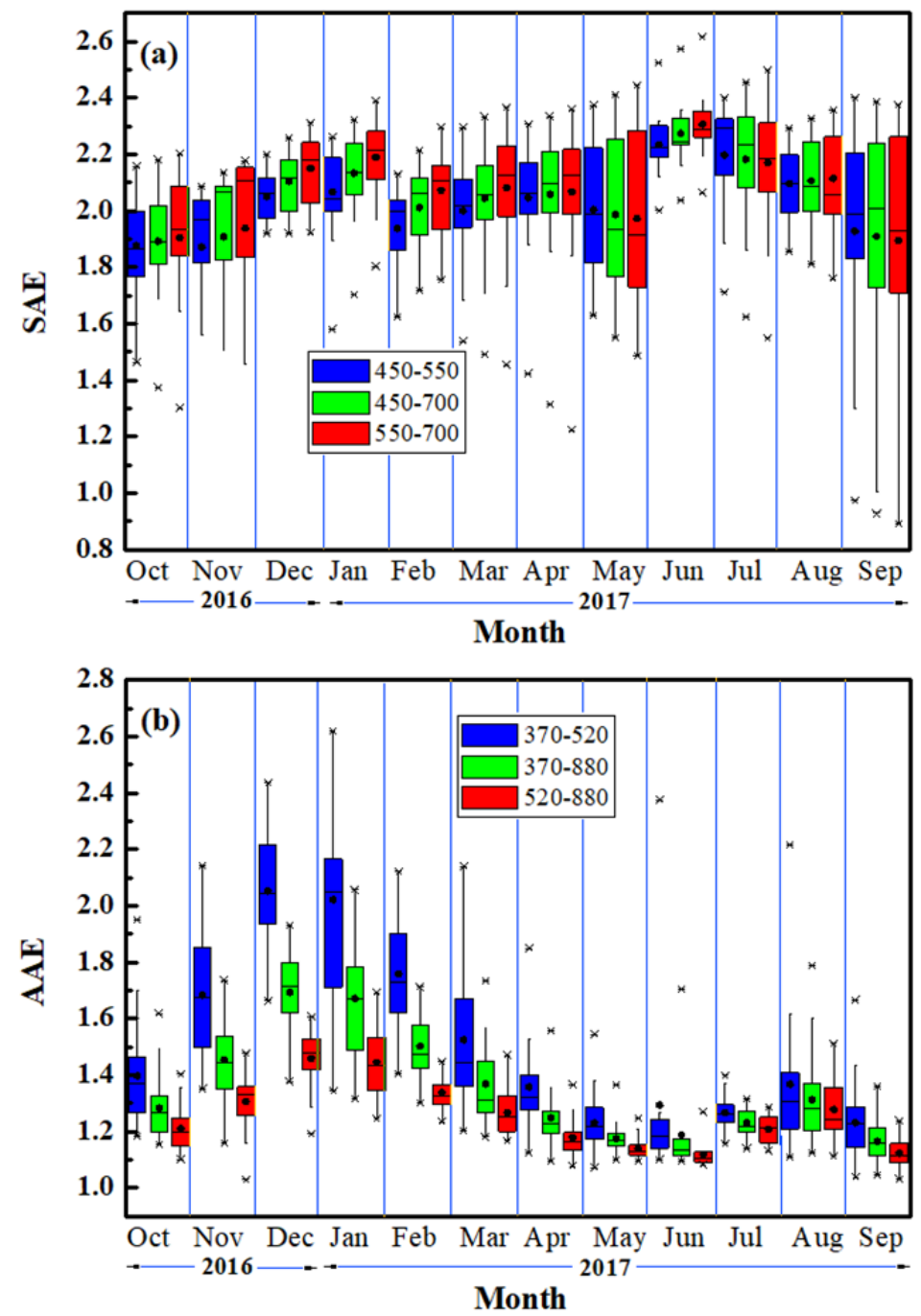

Fig. 7. Monthly values of the (a) SAE and (b) AAE at three wavelength bands over Athens from October 2016 to September 2017, excluding the rainy and dusty days. The box's upper and lower limits are the 75 and 25 percentiles, respectively, the black circle corresponds to the mean and the straight line denotes the median. The whiskers denote the 95 and 5 percentiles.

fossil-fuel combustion (Russel et al., 2010; Cazorla et al., 2013; Srivastava et al., 2014). Fig. 10 correlates the hourly $\mathrm{SAE}_{450-700}$ and $\mathrm{AAE}_{370-880}$ in Athens as a function of month (colored scale), indicating that the high AAE and SAE values correspond to months during the cold period (November-February), implying for significant impact of residential wood burning (Fourtziou et al., 2017). Cases with desert dust are absent (the dusty and rainy days have been excluded), while cases with AAE in the range of 1.11.3 and SAE values below 1.4 correspond to mixing of fossil-fuel emissions with other aerosols from coarser size, like re-suspended dust. More detailed analysis is needed for the classification of the various aerosol types via the AAE vs. SAE scatter plot and examination of the emission sources, taking also into account the SSA, BC concentrations and chemical composition.

\section{Single Scattering Albedo}

The exclusion of the rainy and dusty days led to a slight increase in the SSA values (Table 1), which ranges from $\sim 0.2$ to 0.9 (mean of $0.66 \pm 0.11$ ) at $550 \mathrm{~nm}$, while the respective means at 450 and $700 \mathrm{~nm}$ were found to be $0.68 \pm 0.11$ and $0.62 \pm 0.12$, respectively. Furthermore, the SSA values were generally lower under weak winds (WS $<3 \mathrm{~m} \mathrm{~s}^{-1}$ ) (Suppl. Fig. S3) indicating accumulation of the fresh urban emissions that are characterized by highly absorbing aerosols (e.g., large fraction of $\mathrm{BC}$ from fossil-fuel emissions). It is characteristic that the mean SSA values are very similar for all months regardless of the wavelength (Fig. 11). SSA values around $0.6-0.7$ have also been reported in Athens via an indirect method of simulating the diffuse/direct irradiance ratio (Kaskaoutis et al., 2016).

The monthly variation of the spectral SSA (Fig. 11) reveals a rather complicated annual pattern for both values and spectral dependence, implying changes in the dominant aerosol types. A decrease of SSA with wavelength is seen in all months, suggesting dominance of urban/industrial aerosols (Dubovik et al., 2002). However, the decreasing 

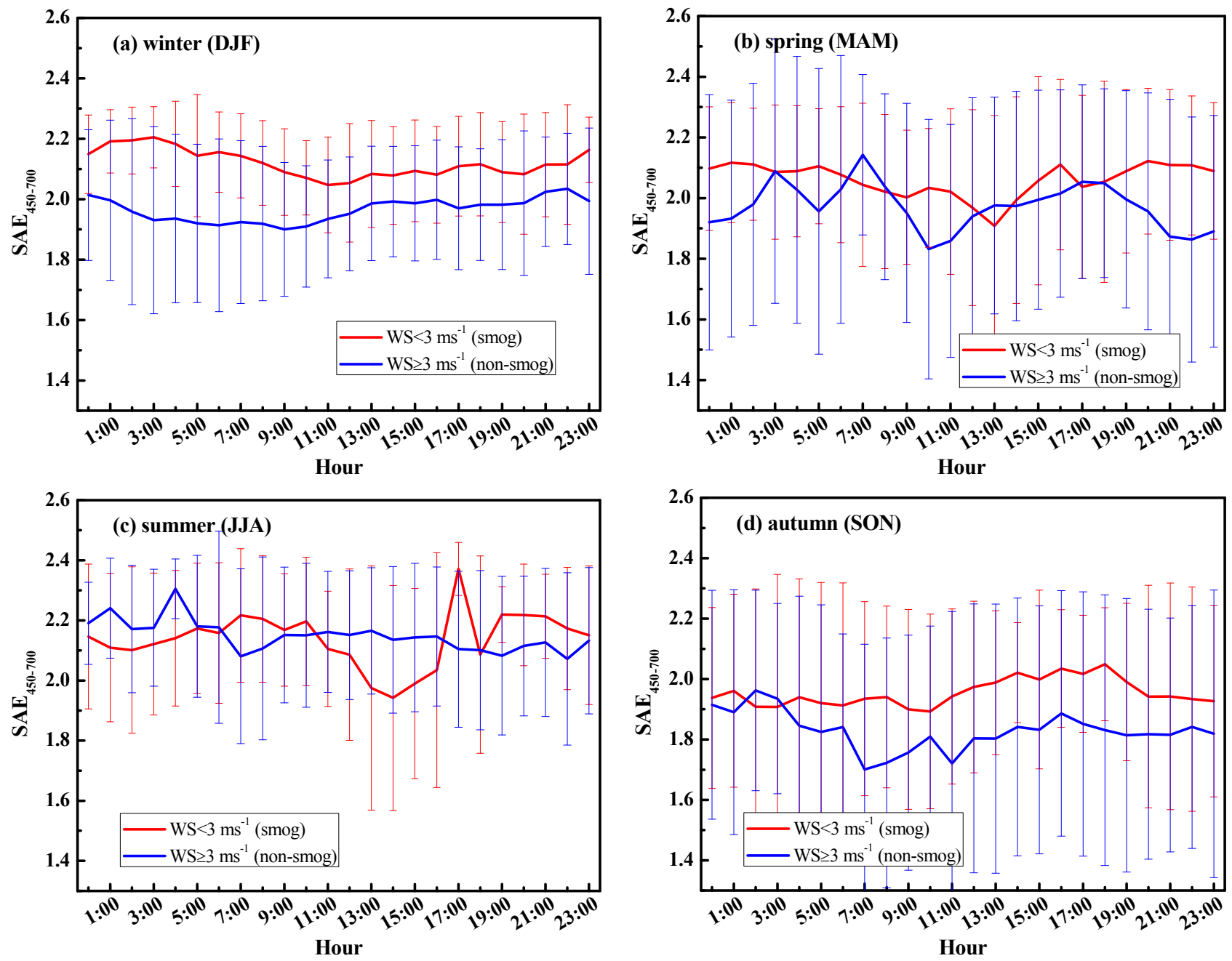

Fig. 8. Seasonal-mean diurnal patterns of the $\mathrm{SAE}_{450-700}$ for cases with wind speeds above and below $3 \mathrm{~m} \mathrm{~s}^{-1}$. The rainy and dusty days have been excluded. The vertical bars correspond to one standard deviation from the hourly mean.

rate in SSA may be further used to apportion the aerosol sources (Patel et al., 2017), since the highest decreasing rates correspond to aerosols with high $\mathrm{BC}$ fraction from fossil-fuel combustion (March-September), while lower spectral variations occur from enhanced presence of OC mixed with BC from wood burning (November-February) (Habib et al., 2008). On the other hand, the SSA is strongly associated with the fraction of absorbing aerosols (mostly $\mathrm{BC}$ ) to the total aerosol mass at the ground and the low SSA values in spring and summer are attributed to the predominance of the urban/anthropogenic aerosols. Previous studies (Virkkula et al., 2011; Lihavainen et al., 2015) reported low SSA values, usually below 0.7 , at Northern European sites during winter due to contribution from residential wood combustion sources, while winter $\mathrm{SSA}_{637}$ of $0.70 \pm 0.09$ was found in Granada, Spain (Titos et al., 2014). Much higher SSA of $0.90 \pm 0.05$ associated with significantly lower SAE values $(1.33 \pm 0.48)$ were reported at a regional site in NE Spain (Pandolfi et al., 2011), indicating large differences in the aerosol types and properties compared to Athens.

The seasonal-mean diurnal patterns of $\mathrm{SSA}_{550}$ reveal distinct differences for the two groups (wind speeds above and below $3 \mathrm{~m} \mathrm{~s}^{-1}$ ) in all seasons except summer (Fig. 12). Therefore, in winter, spring and autumn, the SSA for the smog cases exhibits a pronounced diurnal pattern with lower values during the morning traffic hours and a progressive increase until noon and early afternoon ( 15:00-16:00 LST). Then, a slight decrease follows until the night hours. The large gap in SSA values during the morning rush traffic hours clearly reveals the influence of the highlyabsorbing BC aerosols from complete combustion (vehicle exhaust) (Dubovik et al., 2002; Kanakidou et al., 2005; Ealo et al., 2018). On the other hand, the SOA formation around noon may increase the SSA as these particles are more efficient scatterers (Sarkar et al., 2017). The respective diurnal patterns for the non-smog cases follow, in general, a similar variation but with a lower range and larger SSA values throughout the day, apart from noon and afternoon hours. This indicates that for WS $\geq 3 \mathrm{~m} \mathrm{~s}^{-1}$ there is higher possibility for dispersion of the urban/traffic emissions and for better mixing with soil aerosols and road-dust resuspension, which are larger particles with higher SSA values. In addition, we also analyzed the diurnal patterns 

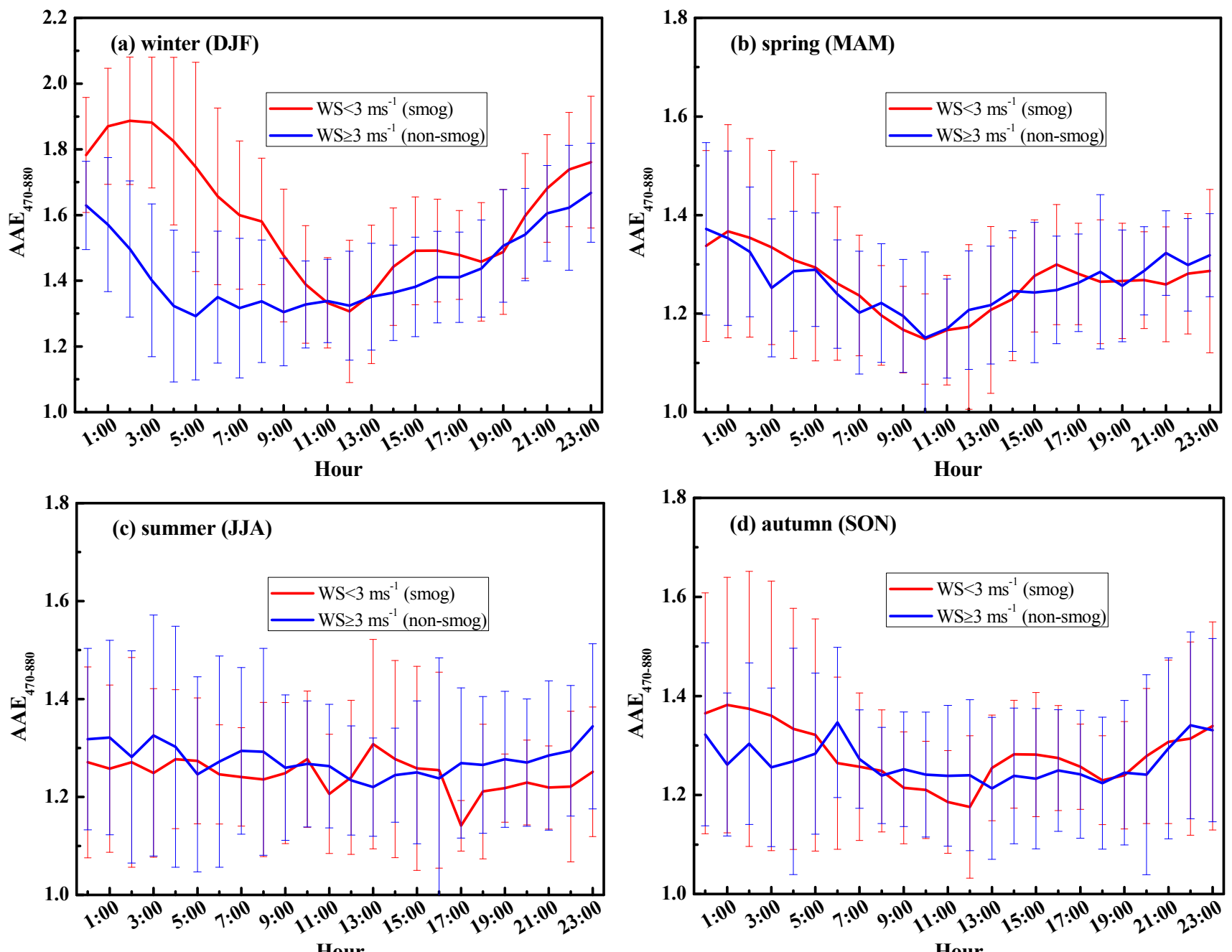

Fig. 9. Seasonal-mean diurnal patterns of the $A A E_{370-880}$ for cases with wind speeds above and below $3 \mathrm{~m} \mathrm{~s}^{-1}$. The rainy and dusty days have been excluded. The vertical bars correspond to one standard deviation from the hourly mean.

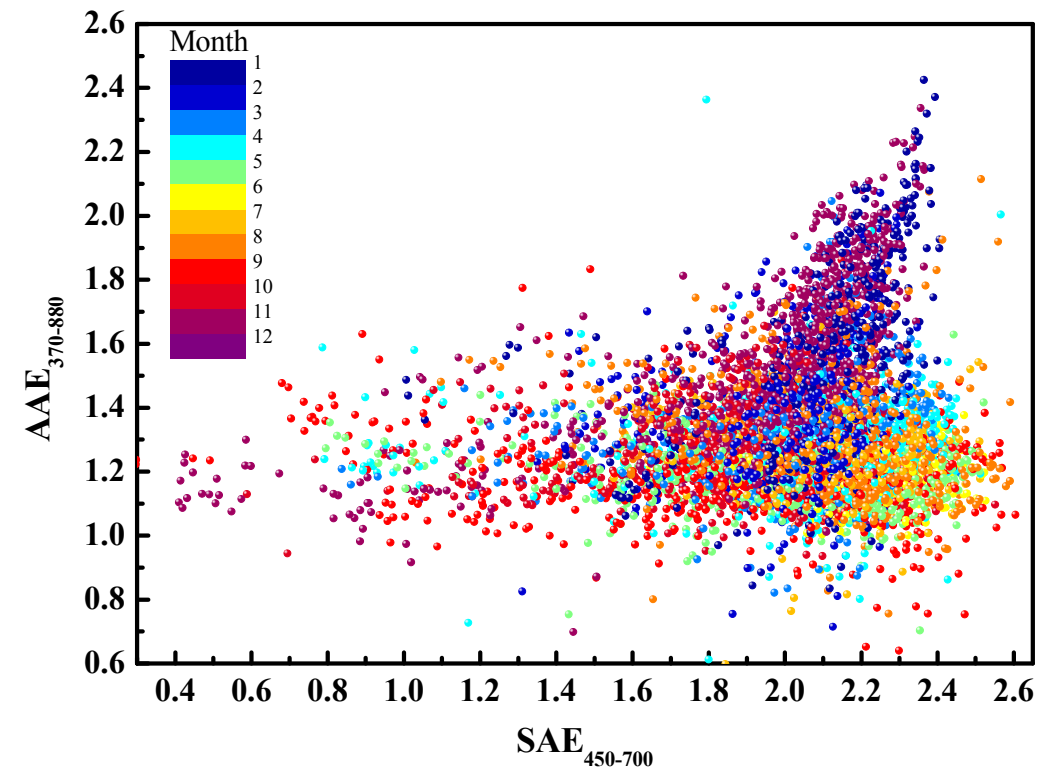

Fig. 10. Scatter plot between $\mathrm{SAE}_{450-700}$ and $\mathrm{AAE}_{370-880}$ hourly values, as a function of month (colored scale) in Athens during the period October 2016-September 2017. 


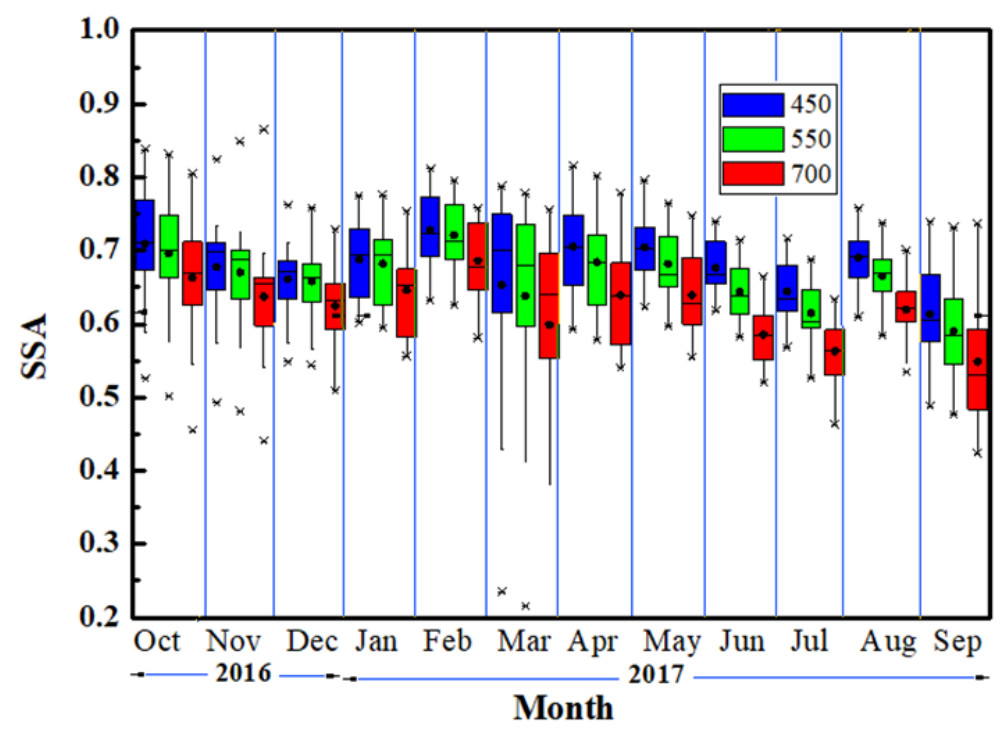

Fig. 11. Monthly values of the spectral SSA over Athens from October 2016 to September 2017, excluding the rainy and dusty days. The box's upper and lower limits are the 75 and 25 percentiles, respectively, the black circle corresponds to the mean and the straight line denotes the median. The whiskers denote the 95 and 5 percentiles.
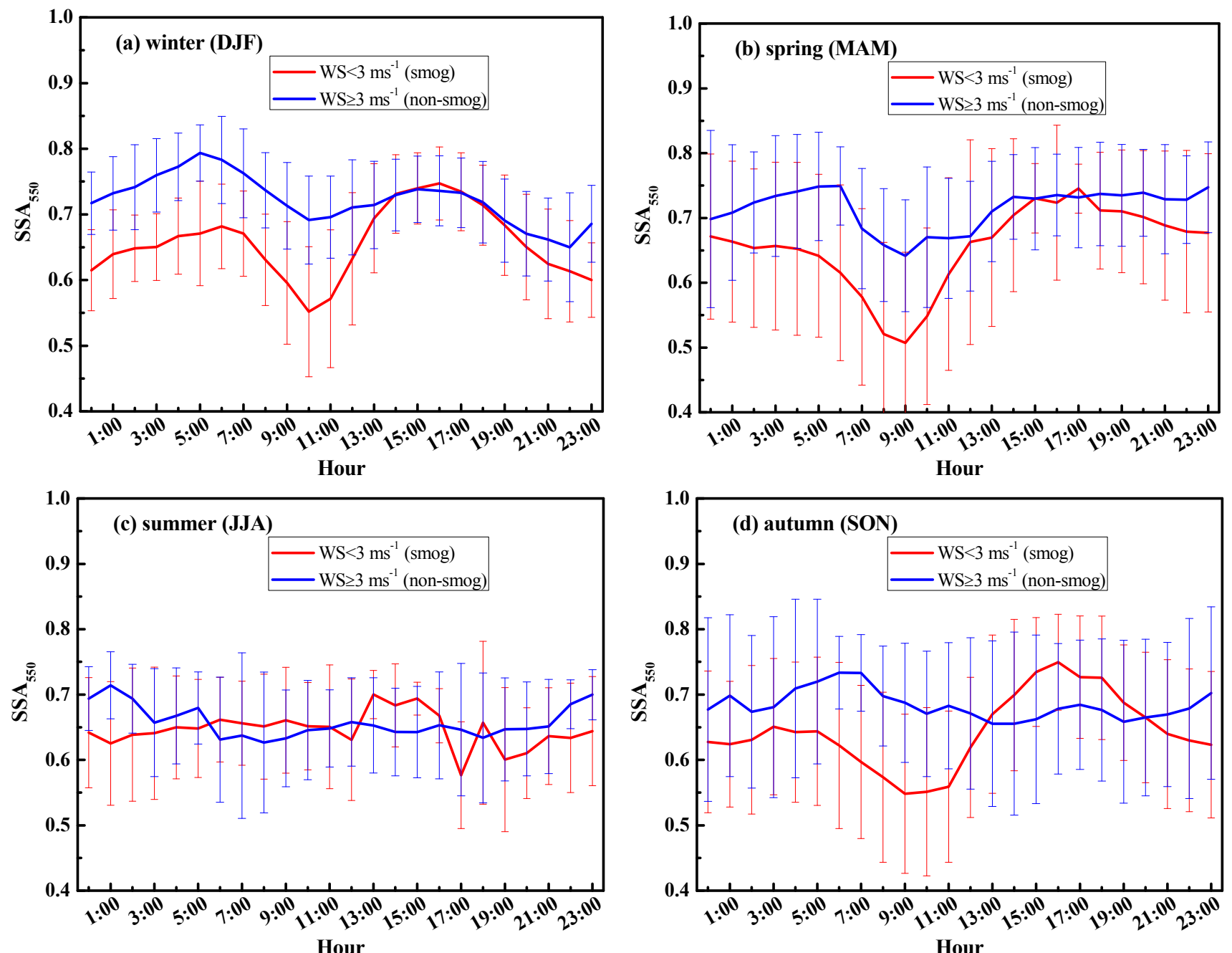

Fig. 12. Seasonal-mean diurnal patterns of the $\mathrm{SSA}_{550}$ for cases with wind speeds above and below $3 \mathrm{~m} \mathrm{~s}^{-1}$. The rainy and dusty days have been excluded. The vertical bars correspond to one standard deviation from the hourly mean. 
of the wavelength dependence of SSA between $450 \mathrm{~nm}$ and $700 \mathrm{~nm}$, expressed via the SSA wavelength exponent ( $\alpha$-SSA), on seasonal basis for the two groups of data (Figs. 13(a)-13(b)). For the smog cases (Fig. 13(a)), the results show lower a-SSA values in winter, characteristic of enhanced levels of biomass-burning aerosols that reflect lesser wavelength dependence of SSA compared to fossilfuel combustion from vehicles and industries (Liu et al., 2014; Stockwell et al., 2016; Schuster et al., 2016). This is also verified by the remarkable increase in $\alpha$-SSA values during the morning rush-traffic hours in all seasons except summer. The summer increase in $\alpha$-SSA during late afternoon-to-evening hours may be also related to increased traffic emissions (entertainment hours). The seasonal-mean diurnal cycles of the $\alpha$-SSA verify the signals of the trafficand biomass-related carbonaceous aerosol emissions in Athens. Lower $\alpha$-SSA values in winter and higher in summer, but without any distinct diurnal cycle, are shown for cases with $\mathrm{WS} \geq 3 \mathrm{~m} \mathrm{~s}^{-1}$, thus corresponding to well-mixed atmospheric conditions in each season with increased fraction of biomass burning in winter (Fig. 13(b)).

\section{Contribution of Chemical Species to Light Scattering}

Apart from the particle size and shape, the aerosol chemical composition also plays a crucial role in the light scattering and absorption processes (Tao et al., 2014; Dumka et al., 2017). In this respect, the reconstruction of the $b_{\text {sca }}$ via chemical components measured with ACSM is attempted, also examining their individual contribution to light scattering in Athens. The daily $b_{\text {sca }}$ values were found to be highly correlated (slope: $0.29, \mathrm{R}^{2}=0.91$ ) with the total chemical mass concentrations via ACSM during the whole campaign. Similarly, strong correlations $\left(\mathrm{R}^{2}=0.94\right.$ $0.97)$ were found between $b_{\text {ext }}$ and mass of anthropogenic aerosols $\left[\mathrm{OM}+\mathrm{EC}+\left(\mathrm{NH}_{4}\right)_{2} \mathrm{SO}_{4}+\mathrm{NH}_{4} \mathrm{NO}_{3}\right]$ over Delhi, while the $b_{\text {ext }}$ was much more weakly dependent on the natural (soil and desert dust) components (Dumka et al., 2017), suggesting that the anthropogenic emissions play the major role in light attenuation in urban environments.

The monthly variation of the cumulative concentrations of the various components in the non-refractory $\mathrm{PM}_{1}$ mass shows higher values during November-February (19$\left.25 \mu \mathrm{g} \mathrm{m}^{-3}\right)$ and much lower $\left(8.3 \mu \mathrm{g} \mathrm{m}^{-3}\right)$ in May (Fig. 14).
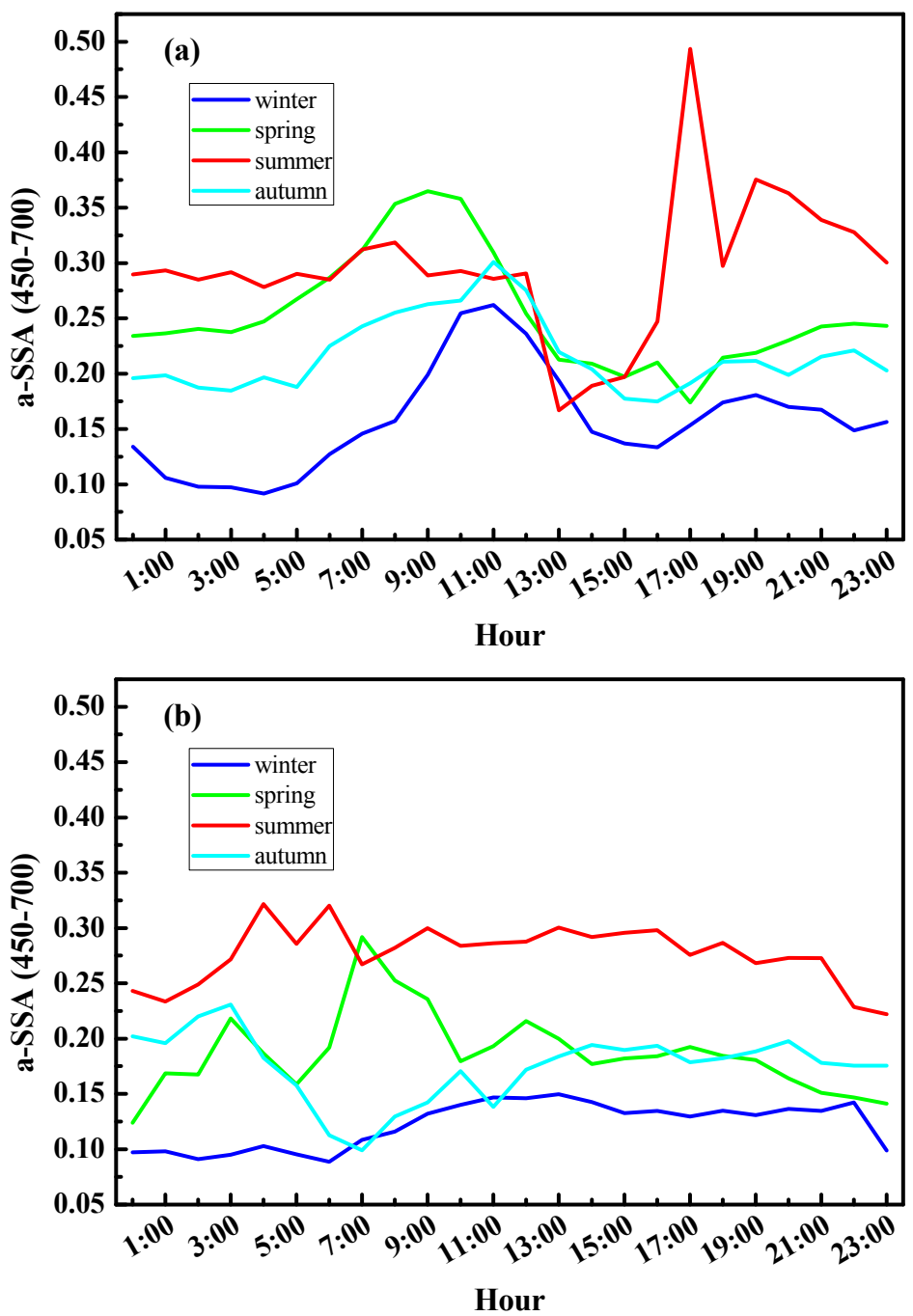

Fig. 13. Seasonal-mean diurnal patterns for the SSA exponent $(\alpha-S S A)$ for $\operatorname{smog}\left(\mathrm{WS}<3 \mathrm{~m} \mathrm{~s}^{-1}\right)$ (a) and non-smog (WS $\geq 3 \mathrm{~m} \mathrm{~s}^{-1}$ ) (b) conditions. The rainy and dusty days have been excluded. 
During the summer months the fine-mode mass concentrations increase $\left(14.2-15.5 \mu \mathrm{g} \mathrm{m}^{-3}\right)$, mostly attributed to the increase of organics and sulfate due to photochemical reactions and enhanced secondary aerosol formation. The average organics, $\mathrm{SO}_{4}{ }^{2-}, \mathrm{NO}_{3}^{-}, \mathrm{BC}$ and $\mathrm{NH}_{4}^{+}$concentrations during the whole period were $7.9 \pm 3.3 \mu \mathrm{g} \mathrm{m}^{-3}, 3.9 \pm$ $0.7 \mu \mathrm{g} \mathrm{m}^{-3}, 0.8 \pm 0.5 \mu \mathrm{g} \mathrm{m}^{-3}, 1.9 \pm 0.7 \mu \mathrm{g} \mathrm{m}^{-3}$, and $1.1 \pm$ $0.2 \mu \mathrm{g} \mathrm{m}^{-3}$, respectively. Organics, $\mathrm{BC}$ and $\mathrm{NO}_{3}{ }^{-}$exhibit the highest concentrations $\left(15.3 \mu \mathrm{g} \mathrm{m}^{-3}, 3.4 \mu \mathrm{g} \mathrm{m}^{-3}\right.$ and $1.8 \mu \mathrm{g} \mathrm{m}^{-3}$, respectively) in December and the lowest in May $\left(3.1 \mu \mathrm{g} \mathrm{m}^{-3}, 1.1 \mu \mathrm{g} \mathrm{m}^{-3}\right.$ and $0.25 \mu \mathrm{g} \mathrm{m}^{-3}$, respectively), while the high correlation between sulfate and ammonium (slope $=3.2 ; \mathrm{R}^{2}=0.77$ ) and between nitrate and chloride $\left(\mathrm{R}^{2}=0.92\right)$ indicates common sources, which for the case of ammonium and sulfate come from secondary aerosol formation and for the case of nitrate and chloride from local combustion processes mostly during wintertime. Based on the ACSM measurements, organics contributed $46.1 \%$ to the total non-refractory submicron mass during summer, followed by sulfate $(31.7 \%)$, BC $(10.7 \%)$ and ammonium $(8.7 \%)$, while during winter, organics and sulfate contributed $57.3 \%$ and $16.3 \%$, respectively, followed by BC (13.3\%), ammonium (5.1\%) and nitrate (7.1\%) (Suppl. Fig. S4). Organic aerosols contribute almost the half to the $\mathrm{PM}_{1}$ mass, on annual average, sulfate exhibits the most seasonally dependent contributions, while an important finding is the $10-14 \%$ contribution of the $\mathrm{BC}$ in all seasons. OC was the major contributor to the $\mathrm{PM}_{2.5}$ mass $(\sim 20-30 \%)$ at urban European sites (Putaud et al., 2010), while its contribution to $\mathrm{PM}_{2.5}$ in Athens has been found to be around $30 \%$ (Pateraki et al., 2011; Theodosi et al., 2011).

The reconstructed $b_{\text {sca }}$ values at $550 \mathrm{~nm}$ are highly correlated with the Nephelometer measurements during the period October 2016-August 2017, with an $\mathrm{R}^{2}=0.91$ (slope: 1.08), and a slight bias of $8 \%$ (Fig. 15). Very good agreement between the measured and modeled $b_{\text {sca }}$ at $525 \mathrm{~nm}\left(\mathrm{R}^{2}=0.88-0.92\right)$, with slopes between 0.96 and 0.98 was also found in NE Spain (Ealo et al., 2018). The relative contributions of each component to the light scattering (Eqs. (4)-(5)) are examined in two periods, i.e., from October to mid-May for POM, AS and AN, and from mid-May to August for POM and AS. POM and AS contribute $51 \%$ and $39 \%$, respectively to the $b_{\text {sca }}$, while AN contributes only by $10 \%$ during October to mid-May. For mid-May to August, the corresponding values for POM and AS were found to be $56.5 \%$ and $43.5 \%$, since nitrate formation is not favored. Similarly, previous studies in eastern (Kalivitis et al., 2011) and western Mediterranean (Pandolfi et al., 2011) found higher concentrations for the ammonium sulfate and POM in summer being important contributors to $b_{\text {sca. }}$. A study over Delhi using the IMPROVE algorithms (Dumka et al., 2017) found that the OM contributed $39 \%$ and $48 \%$ to the $b_{\text {ext }}$, followed by $\left(\mathrm{NH}_{4}\right)_{2} \mathrm{SO}_{4}$ (21\% and 24\%), Elemental Carbon (EC) (13\% and 10\%) and $\mathrm{NH}_{4} \mathrm{NO}_{3}(9 \%$ and $5 \%)$. A similar approach applied in China (Cao et al., 2012) revealed largest contributions to $\mathrm{b}_{\mathrm{ext}}$ by $\left(\mathrm{NH}_{4}\right)_{2} \mathrm{SO}_{4}(40 \%), \mathrm{OM}(24 \%), \mathrm{NH}_{4} \mathrm{NO}_{3}(23 \%)$ and EC $(9 \%)$. The carbonaceous aerosols contributed also the largest fraction (OM: $39 \%$ and EC: $20 \%$ ) to $b_{\text {ext }}$ in the polluted Pearl River Delta, China, followed by $\left(\mathrm{NH}_{4}\right)_{2} \mathrm{SO}_{4}$ (16\%), coarse mode $(13 \%)$ and $\mathrm{NH}_{4} \mathrm{NO}_{3}(11.8 \%)$ (Zhang et al., 2013).

\section{SUMMARY AND CONCLUSIONS}

The seasonality of the spectral variation in the nearsurface aerosol properties, namely, the scattering and absorption coefficients, along with spectral SSA calculations via combined Nephelometer and Aethalometer measurements, were examined in the Athens urban environment from October 2016 to September 2017. The analysis was complemented by concurrent measurements of chemical species (organics, BC, sulfate, nitrate, ammonium and chloride) via ACSM, air pollutants (CO and NO), PM concentrations and meteorological observations. The main objectives were to reveal the near-surface urban aerosol characteristics and to assess the influence of different combustion sources (vehicle exhaust, industry, bio-fuel

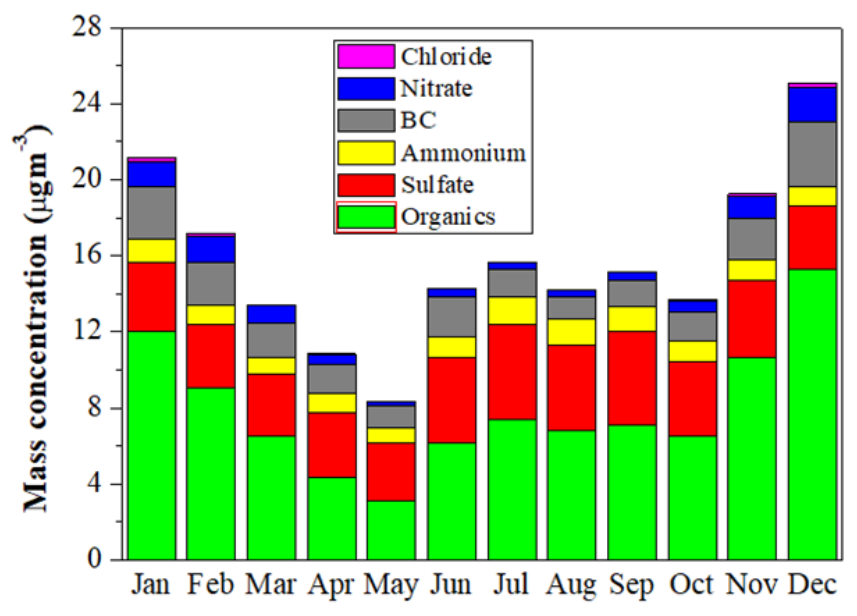

Month

Fig. 14. Monthly variation of the cumulative mass concentrations of the $\mathrm{PM}_{1}$ non-refractory chemical components via ACSM measurements at Thissio, Athens during October 2016-September 2017. 


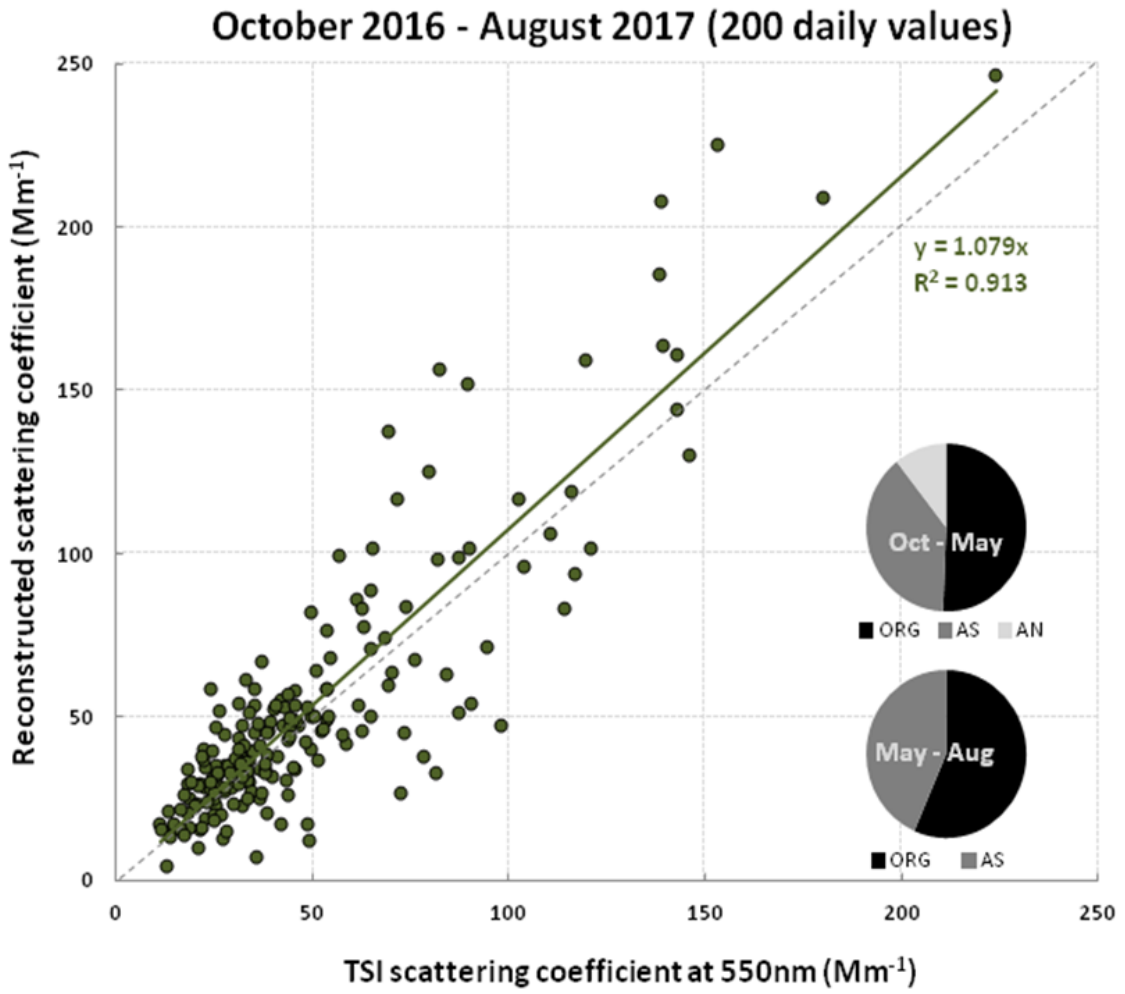

Fig. 15. Scatter plot between the reconstructed and measured $b_{\text {sca }}$ (at $550 \mathrm{~nm}$ ) daily values during the period October 2016 to August 2017. The contributions of the individual chemical species for the cold (October-mid-May) and warm (midMay-August) seasons are also given in the graph.

and wood burning) on the extensive and intensive aerosol properties in each season. Furthermore, the contribution of the major chemical species to the $b_{\text {sca }}$ was evaluated, as well as the influence of local and regional combustion sources from traffic and wood burning on aerosol optical properties and pollutant emissions.

The $b_{\text {sca }}$ and $b_{a b s}$ exhibited a high temporal variation and a distinct seasonality with larger values in winter and lower ones in spring and summer. Annual means of $46.0 \pm$ $32.2 \mathrm{Mm}^{-1}$ for the $b_{\text {sca }}$ at $550 \mathrm{~nm}$ and of $28.4 \pm 36.3 \mathrm{Mm}^{-1}$ for the $b_{a b s}$ at $520 \mathrm{~nm}$ were found, and the mean value for the SSA was $0.62 \pm 0.11$ at $550 \mathrm{~nm}$. The large increase in both the $b_{\text {sca }}$ and $b_{a b s}$ in the last week of November and during winter was attributed to enhanced residential wood burning emissions from heating, as the economic recession during the recent years in Greece has prompted people to use fireplaces instead of the more expensive fossil fuels. The residential wood burning emissions left their signal on the aerosol optical properties via the high $b_{\text {sca }}, b_{a b s}$ and PM concentrations and the large $\operatorname{SAE}(\sim 2.1)$ and $\operatorname{AAE}(>1.5)$ values from November to February, indicating the accumulation of sub-micron aerosols, with a significant fraction of organic carbon from biomass burning. During the rest of the year, the $b_{\text {sca }}$ and $b_{a b s}$ values were much lower, with AAE values in the range of 1.1-1.2, indicating the dominance of aerosols from fossil-fuel combustion (vehicle exhaust and industry). By contrast, the SAE values remained high $(\sim 2.0)$ throughout the year, suggesting the dominance of fine urban/anthropogenic aerosols. Further analysis of the diurnal variations of the spectral $b_{\text {sca }}$ and $b_{a b s}$ revealed two peaks during the morning and evening/night hours, due to traffic-related and wood burning emissions, respectively. These diurnal cycles were clearly detected during the autumn and winter and in cases with wind speeds below $3 \mathrm{~m} \mathrm{~s}^{-1}$, characterized as smoggy conditions. In the other seasons and with higher wind speeds, any diurnal variation tended to flatten out, indicating that apart from the local emissions, the boundary-layer dynamics and changes in wind speed are important factors in controlling the aerosol load and properties in Athens. The reconstructed $b_{\text {sca }}$ values via the chemical closure analysis showed very good agreement with the measurements $\left(\mathrm{R}^{2}=0.91\right.$; bias of $\left.8 \%\right)$. Organic matter was found to be the largest contributor $(\sim 51 \%)$ to the $b_{\text {sca }}$ from October to mid-May, followed by ammonium sulfate $(\sim 39 \%)$ and ammonium nitrate $(\sim 10 \%)$.

\section{ACKNOWLEDGEMENTS}

The financial support by the European Community through the ACTRIS Research Infrastructure Action under the $7^{\text {th }}$ Framework Programme (Grant Agreement No. 262254) is gratefully acknowledged. The analysis was partly supported by ERA-PLANET (www.era-planet.eu), trans-national project SMURBS (www.smurbs.eu) (Grant Agreement No. 689443), funded under the EU Horizon 2020 Framework Programme. The authors want to thank the editor and the anonymous reviewers for their comments, which helped improved the initially submitted version. 


\section{SUPPLEMENTARY MATERIAL}

Supplementary data associated with this article can be found in the online version at http://www.aaqr.org.

\section{REFERENCES}

Alsaaideh, B., Tateishi, R., Phong, D.X., Hoan, N.T., AlHanbali, A. and Xiulian, B. (2017). New urban map of Eurasia using MODIS and multi-source geospatial data. Geo-spatial Inf. Sci. 20: 29-38.

Andreae, M.O. and Gelencsér, A. (2006). Black carbon or brown carbon? The nature of light absorbing carbonaceous aerosols. Atmos. Chem. Phys. 6: 3131-3148.

Antón, M., Valenzuela, A., Cazorla, A., Gil, J.E., Fernández-Gálvez, J., Lyamani, H., Foyo-Moreno, I., Olmo, F.J. and Alados-Arboledas, L. (2012). Global and diffuse shortwave irradiance during a strong desert dust episode at Granada (Spain). Atmos. Res. 118: 232-239.

Athanasopoulou, E., Protonotariou, A., Papangelis, G., Tombrou, M., Mihalopoulos, N. and Gerasopoulos, E. (2016). Long-range transport of Saharan dust and chemical transformations over the Eastern Mediterranean. Atmos. Environ. 140: 592-604.

Athanasopoulou, E., Speyer, O., Brunner, D., Vogel, H., Vogel, B., Mihalopoulos, N. and Gerasopoulos, E. (2017). Changes in the domestic heating fuel in Greece: Effects onatmospheric chemistry and radiation. Atmos. Chem. Phys. 17: 10597-10618.

Backman, J., Schmeisser, L., Virkkula, A., Ogren, J.A., Asmi, E., Starkweather, S., Sharma, S., Eleftheriadis, K., Uttal, T., Jefferson, A., Bergin, M., Makshtas, A., Tunved, P. and Fiebig, M. (2017). On Aethalometer measurement uncertainties and an instrument correction factor for the Arctic. Atmos. Meas. Tech. 10: 5039-5062.

Bergstrom, R.W., Pilewskie, P., Russell, P.B., Redemann, J., Bond, T.C., Quinn, P.K. and Sierau, B. (2007). Spectral absorption properties of atmospheric aerosols. Atmos. Chem. Phys. 7: 5937-5943.

Bisht, D.S., Dumka, U.C., Kaskaoutis, D.G., Pipal, A.S., Srivastava, A.K., Soni, V., Attri, S.D., Sateesh, M. and Tiwari, S. (2015). Carbonaceous aerosols and pollutants over Delhi urban environment: Temporal evolution, source apportionment and radiative forcing. Sci. Total Environ. 521-522: 431-445.

Cao, J., Wang, Q.Y., Chow, J.C., Watson, J.G., Tie, X.X., Shen, Z.X., Wang, P. and An, Z.S. (2012). Impacts of aerosol compositions on visibility impairment in Xi'an. China. Atmos. Environ. 59: 559-566.

Cazorla, A., Bahadur, R., Suski, K.J., Cahill, J.F., Chand, D., Schmid, B., Ramanathan, V. and Prather, K.A. (2013). Relating aerosol absorption due to soot, organic carbon, and dust to emission sources determined from in-situ chemical measurements. Atmos. Chem. Phys. 13: 9337-9350.

Cheng, Z., Jiang, J., Chen, C., Gao, J., Wang, S., Watson, J.G., Wang, H., Deng, J., Wang, B., Zhou, M., Chow, J.C., Pitchford, M.L. and Hao, J. (2015). Estimation of aerosol mass scattering efficiencies under high mass loading: case study for the megacity of Shanghai, China. Environ. Sci. Technol. 49: 831-838.

Cohen, J.B. and Wang, C. (2014). Estimating global black carbon emissions using a top-down Kalman filter approach. J. Geophys. Res. 119: 307-323.

Collaud Coen, M., Weingartner, E., Apituley, A., Ceburnis, D., Fierz-Schmidhauser, R., Flentje, H., Henzing, J.S., Jennings, S.G., Moerman, M., Petzold, A., Schmid, O. and Baltensperger, U. (2010). Minimizing light absorption measurement artifacts of the Aethalometer: Evaluation of five correction algorithms. Atmos. Meas. Tech. 3: 457-474.

Day, D.E., Hand, J.L., Carrico, C.M., Engling, G. and Malm, W.C. (2006). Humidification factors from laboratory studies of fresh smoke from biomass fuels. $J$. Geophys. Res. 111: D22202.

Diapouli, E., Kalogridis, A.C., Markantonaki, C., Vratolis, S., Fetfatzis, P., Colombi, C. and Eleftheriadis, K. (2017c). Annual variability of Black Carbon concentrations originating from biomass and fossil fuel combustion for the suburban aerosol in Athens, Greece. Atmosphere 8: 234.

Diapouli, E., Manousakas, M.I., Vratolis, S., Vasilatou, V., Pateraki, S., Bairachtari, K.A., Querol, X., Amato, F., Alastuey, A., Karanasiou, A.A., Lucarelli, F., Nava, S., Calzolai, G., Gianelle, V.L., Colombi, C., Alves, C., Custódio, D., Pio, C., Spyrou, C., Kallos, G.B. and Eleftheriadis, K. (2017a). AIRUSE-LIFE +: Estimation of natural source contributions to urban ambient air $\mathrm{PM}_{10}$ and $\mathrm{PM}_{2.5}$ concentrations in southern Europe implications to compliance with limit values. Atmos. Chem. Phys. 17: 3673-3685.

Diapouli, E., Manousakas, M., Vratolis, S., Vasilatou, V., Maggos, T., Saraga, D., Grigoratos, T., Argyropoulos, G., Voutsa, D., Samara, C. and Eleftheriadis, K. (2017b). Evolution of air pollution source contributions over one decade, derived by $\mathrm{PM}_{10}$ and $\mathrm{PM}_{2.5}$ source apportionment in two metropolitan urban areas in Greece. Atmos. Environ. 164: 416-430.

Drinovec, L., Mocnik, G., Zotter, P., Prévôt, A.S.H., Ruckstuhl, C., Coz, E., Rupakheti, M., Sciare, J., Müller, T., Wiedensohler, A. and Hansen, A.D.A. (2015). The "dual-spot" Aethalometer: An improved measurement of aerosol black carbon with realtime loading compensation. Atmos. Meas. Tech. 8: 1965-1979.

Dubovik, O., Holben, B.N, Eck, T.F., Smirnov, A., Kaufman, Y.J., King, M.D., Tanrè, D. and Slutsker, I. (2002). Variability of absorption and optical properties of key aerosol types observed in worldwide locations. $J$. Atmos. Sci. 59: 590-608.

Dumka, U.C. and Kaskaoutis, D.G. (2014). In-situ measurements of aerosol properties and estimates of radiative forcing efficiency over Gangetic-Himalayan region during the GVAX field campaign. Atmos. Environ. 94: 96-105.

Dumka, U.C., Kaskaoutis, D.G., Srivastava, M.K. and Devara, P.C.S. (2015). Scattering and absorption properties of near-surface aerosol over Gangetic-Himalayan region: The role of boundary-layer dynamics and long-range 
transport. Atmos. Chem. Phys. 15: 1555-1572.

Dumka, U.C., Tiwari, S., Kaskaoutis, D.G., Hopke, P.K., Singh, J., Srivastava, A.K., Bisht, D.S., Attri, S.D., Tyagi, S., Misra, A. and Pasha, G.S.M. (2017). Assessment of $\mathrm{PM}_{2.5}$ chemical compositions in Delhi: Primary vs. secondary emissions and contribution to light extinction coefficient and visibility degradation. J. Atmos. Chem. 74: 423-450.

Ealo, M., Alastuey, A., Pérez, N., Ripoll, A., Querol, X. and Pandolfi, M. (2017). Impact of aerosol particle sources on optical properties in urban, regional and remote areas in the north-western Mediterranean. Atmos. Chem. Phys. 18: 1149-1169.

Eck, T.F., Holben, B.N., Ward, D.E., Mukelabai, M.M., Dubovik, O., Smirnov, A., Schafer, J.S., Hsu, N.C., Piketh, S.J., Queface, A., Roux, J.L., Swap, R.J. and Slutsker, I. (2003). Variability of biomass burning aerosol optical characteristics in southern Africa during SAFARI 2000 dry season campaign and a comparison of single scattering albedo estimates from radiometric measurements. J. Geophys. Res. 108: 8477.

Eck, T.F., Holben, B.N., Dubovik, O., Smirnov, A., Goloub, P., Chen, H.B., Chatenet, B., Gomes, L., Zhang, X.Y., Tsay, S.C., Ji, Q., Giles, D. and Slutsker, I. (2005). Columnar aerosol optical properties at AERONET sites in central eastern Asia and aerosol transport to the tropical mid-Pacific. J. Geophys. Res. 110: D06202.

Fourtziou, L., Liakakou, E., Stavroulas, I., Theodosi, C., Zarmpas, P., Psiloglou, B., Sciare, J., Maggos, T., Bairachtari, K., Bougiatioti, A., Gerasopoulos, E., Sarda-Estève, R., Bonnaire, N. and Mihalopoulos, N. (2017). Multi-tracer approach to characterize domestic wood burning in Athens (Greece) during wintertime. Atmos. Environ. 148: 89-101.

Gerasopoulos, E., Andreae, M.O., Zerefos, C.S., Andreae, T.W., Balis, D., Formenti, P., Merlet, P., Amiridis, V. and Papastefanou, C. (2003). Climatological aspects of aerosol optical properties in Northern Greece. Atmos. Chem. Phys. 3: 2025-2041.

Gerasopoulos, E., Koulouri, E., Kalivitis, N., Kouvarakis, G., Saarikoski, S., Mäkelä, T., Hillamo, R. and Mihalopoulos, N. (2007). Size-segregated mass distributions of aerosols over Eastern Mediterranean: Seasonal variability and comparison with AERONET columnar size-distributions. Atmos. Chem. Phys. 7: 2551-2561.

Gerasopoulos, E., Amiridis, V., Kazadzis, S., Kokkalis, P., Eleftheratos, K., Andreae, M.O., Andreae, T.W., ElAskary, H. and Zerefos, C.S. (2011). Three-year ground based measurements of aerosol optical depth over the Eastern Mediterranean: The urban environment of Athens. Atmos. Chem. Phys. 11: 2145-2159.

Gkikas, A., Hatzianastassiou, N., Mihalopoulos, N., Katsoulis, V., Kazadzis, S., Pey, J., Querol, X. and Torres, O. (2013). The regime of desert dust episodes in the Mediterranean based on contemporary satellite observations and ground measurements. Atmos. Chem. Phys. 13: 12135-12154.

Gratsea, M., Liakakou, E., Mihalopoulos, N., Adamopoulos,
A., Tsilibari, E. and Gerasopoulos, E. (2017). The combined effect of reduced fossil fuel consumption and increasing biomass combustion on Athens' air quality, as inferred from long term CO measurements. Sci. Total Environ. 592: 115-123.

Grivas, G., Chaloulakou, A. and Kassomenos, P. (2008). An overview of the $\mathrm{PM}_{10}$ pollution problem, in the Metropolitan Area of Athens, Greece. Assessment of controlling factors and potential impact of long range transport. Sci. Total Environ. 389: 165-177.

Grivas, G., Cheristanidis, S., Chaloulakou, A., Koutrakis, P. and Mihalopoulos, N. (2018). Elemental composition and source apportionment of fine and coarse particles at traffic and urban background locations in Athens, Greece. Aerosol Air Qual. Res. 18: 1642-1659.

Habib, G., Venkataraman, C., Bond, T.C. and Schauer, J.J. (2008). Chemical, microphysical and optical properties of primary particles from the combustion of biomass fuels. Environ. Sci. Technol. 42: 8829-8834.

Hatzianastassiou, N., Katsoulis, B. and Vardavas, I. (2004). Sensitivity analysis of aerosol direct radiative forcings in the ultraviolet - visible wavelengths and consequences for the heat budget. Tellus 56B: 368-381.

He, X., Li, C.C., Lau, A.K.H., Deng, Z.Z., Mao, J.T., Wang, M.H. and Liu, X.Y. (2009). An intensive study of aerosol optical properties in Beijing urban area. Atmos. Chem. Phys. 9: 8903-8915.

Heintzenberg, J., Wiedensohler, A., Tuch, T.M., Covert, D.S., Sheridan, P., Ogren, J.A., Gras, J., Nessler, R., Kleefeld, C., Kalivitis, N., Aaltonen, V., Wilhelm, R.T. and Havlicek, M. (2006). Intercomparison and aerosol calibrations of 12 commercial integrating Nephelometer of three manufacturers. J. Atmos. Oceanic Technol. 23: 902-914.

IPCC (2013). Climate Change 2013: The physical science basis. Working Group I contribution to the IPCC fifth assessment report, Final Draft Underlying ScientificTechnical Assessment. Cambridge University Press, Cambridge, United Kingdom and New York, NY, USA.

Kalivitis, N., Bougiatioti, A., Kouvarakis, G. And Mihalopoulos, N. (2011). Long term measurements of atmospheric aerosol optical properties in the Eastern Mediterranean. Atmos. Res. 102: 351-357.

Kalogridis, A.C., Vratolis, S., Liakakou, E., Gerasopoulos, E., Mihalopoulos, N. and Eleftheriadis, K. (2017). Assessment of wood burning versus fossil fuel contribution to wintertime black carbon and carbon monoxide concentrations in Athens, Greece. Atmos. Chem. Phys. 18: 10219-10236.

Kanakidou, M., Seinfeld, J.H., Pandis, S.N., Barnes, I., Dentener, F.J., Facchini, M.C., Van Dingenen, R., Ervens, B., Nenes, A., Nielsen, C.J., Swietlicki, E., Putaud, J.P., Balkanski, Y., Fuzzi, S., Horth, J., Moortgat, G.K., Winterhalter, R., Myhre, C.E.L., Tsigaridis, K., Vignati, E., Stephanou, E.G. and Wilson, J. (2005). Organic aerosol and global climate modelling: A review. Atmos. Chem. Phys. 5: 1053-1123.

Kanakidou, M., Mihalopoulos, N., Kindap, T., Im, U., Vrekoussis, M., Gerasopoulos, E., Dermitzaki, E., Unal, 
A., Kocak, M., Markakis, K., Melas, D., Kouvarakis, G., Youssef, A.F., Richter, A., Hatzianastassiou, N., Hilboll, A., Ebojie, F., Wittrock, F., von Savigny, C., Burrows, J.P., Ladstaetter-Weissenmayer, A. and Moubasher, H. (2011). Megacities as hot spots of air pollution in the East Mediterranean. Atmos. Environ. 45: 1223-1235.

Kaskaoutis, D.G., Kambezidis, H.D., Dumka, U.C. and Psiloglou, B.E. (2016). Dependence of the spectral diffusedirect irradiance ratio on aerosol spectral distribution and single scattering albedo. Atmos. Res. 178-179: 84-94.

Kirchstetter, T.W., Novakov, T. and Hobbs, P.V. (2004). Evidence that the spectral dependence of light absorption by aerosols is affected by organic carbon. J. Geophys. Res. 109: D21208.

Kosmopoulos, P.G., Kazadzis, S., Taylor, M., Athanasopoulou, E., Speyer, O., Raptis, P.I., Marinou, E., Proestakis, E., Solomos, S., Gerasopoulos, E., Amiridis, V., Bais, A. and Kontoes, C. (2017). Dust impact on surface solar irradiance assessed with model simulations, satellite observations and ground-based measurements. Atmos. Meas. Tech. 10: 2435-2453.

Koyuncu, T. and Pinar, Y. (2007). The emissions from a space-heating biomass stove. Biomass Bioenergy 31: 73-79.

Kumar, N.K., Corbin, J.C., Bruns, E.A., Massabó, D., Slowik, J.G., Drinovec, L., Močnik, G., Prati, P., Vlachou, A., Baltensperger, U., Gysel, M., El-Haddad, I. and Prévôt, A.S.H. (2018). Production of particulate brown carbon during atmospheric aging of wood burning emissions. Atmos. Chem. Phys. Discuss., in Review.

Lee, J., Yun, J. and Kim, K.J. (2016). Monitoring of black carbon concentration at an inland rural area including fixed sources in Korea. Chemosphere 143: 3-9.

Lihavainen, H., Asmi, E., Aaltonen, V., Makkonen, U. and Kerminen, V.M. (2015). Direct radiative feedback due tobiogenic secondary organic aerosol estimated from boreal forest site observations. Environ. Res. Lett. 10: 39.

Liu, D., Allan, J.D., Young, D.E., Coe, H., Beddows, D., Fleming, Z.L., Flynn, M.J., Gallagher, M.W., Harrison, R.M., Lee, J., Prevot, A.S.H., Taylor, J.W., Yin, J., Williams, P.I. and Zotter, P. (2014). Size distribution, mixing state and source apportionment of black carbon aerosol in London during wintertime. Atmos. Chem. Phys. 14: 10061-10084.

Ma, N., Birmili, W., Müller, T., Tuch, T., Cheng, Y.F., Xu, W.Y., Zhao, C.S. and Wiedensohler, A. (2014). Tropospheric aerosol scattering and absorption over central Europe: A closure study for the dry particle state. Atmos. Chem. Phys. 14: 6241-6259.

Malm, W.C. and Hand, J.L. (2007). An examination of the physical and optical properties of aerosols collected in the IMPROVE program. Atmos. Environ. 41: 3407-3427.

Minguillón, M.C., Ripoll, A., Pérez, N., Prévôt, A.S.H., Canonaco, F., Querol, X. and Alastuey, A. (2015). Chemical characterization of submicron regional background aerosols in the western Mediterranean using an Aerosol Chemical Speciation Monitor. Atmos. Chem. Phys. 15: 6379-6391.

Moorthy, K.K., Nair, V.S., Babu, S.S. and Satheesh, S.K.
(2009). Spatial and vertical heterogeneities in aerosol properties over oceanic regions around India: Implications for radiative forcing. Q. J. R. Meteorolog. Soc. 135: 2131-2145.

Moosmüller, H., Engelbrecht, J.P., Skiba, M., Frey, G., Chakrabarty, R.K. and Arnott, W.P. (2012). Single scattering albedo of fine mineral dust aerosols controlled by iron concentration. J. Geophys. Res. 117: D11210.

Ng, N.L., Herndon, S.C., Trimborn, A., Canagaratna, M.R., Croteau, P., Onasch, T.M., Sueper, D., Worsnop, D.R., Zhang, Q., Sun, Y.L. and Jayne, J.T. (2011). An Aerosol Chemical Speciation Monitor (ACSM) for routine monitoring of atmospheric aerosol composition. Aerosol Sci. Technol. 45: 770-784.

Pandolfi, M., Alados-Arboledas, L., Alastuey, A., Andrade, M., Angelov, C., Artiñano, B., Backman, J., Baltensperger, U., Bonasoni, P., Bukowiecki, N., Collaud Coen, M., Conil, S., Coz, E., Crenn, V., Dudoitis, V., Ealo, M., Eleftheriadis, K., Favez, O., Fetfatzis, P., Fiebig, M., Flentje, H., Ginot, P., Gysel, M., Henzing, B., Hoffer, A., Holubova Smejkalova, A., Kalapov, I., Kalivitis, N., Kouvarakis, G., Kristensson, A., Kulmala, M., Lihavainen, H., Lunder, C., Luoma, K., Lyamani, H., Marinoni, A., Mihalopoulos, N., Moerman, M., Nicolas, J., O'Dowd, C., Petäjä, T., Petit, J.E., Pichon, J.M., Prokopciuk, N., Putaud, J.P., Rodríguez, S., Sciare, J., Sellegri, K., Swietlicki, E., Titos, G., Tuch, T., Tunved, P., Ulevicius, V., Vaishya, A., Vana, M., Virkkula, A., Vratolis, S., Weingartner, E., Wiedensohler, A. and Laj, P. (2018). A European aerosol phenomenology-6: Scattering properties of atmospheric aerosol particles from 28 ACTRIS sites. Atmos. Chem. Phys. 18: 7877-7911.

Pandolfi, M., Cusack, M., Alastuey, A. and Querol, X. (2011). Variability of aerosol optical properties in the Western Mediterranean Basin. Atmos. Chem. Phys. 11: 8189-8203.

Panopoulou, A., Liakakou, E., Gros, V., Sauvage, S., Locoge, N., Bonsang, B., Psiloglou, B.E., Gerasopoulos, E. and Mihalopoulos, N. (2017). Non Methane Hydrocarbons variability in Athens during wintertime: The role of traffic and heating. Atmos. Chem. Phys. Discuss., in Review.

Papadimas, C.D., Hatzianastassiou, N., Matsoukas, C., Kanakidou, M., Mihalopoulos, N. and Vardavas, I. (2012). The direct effect of aerosols on solar radiation over the broader Mediterranean basin. Atmos. Chem. Phys. 12: 7165-7185.

Paraskevopoulou, D. (2014). Correlation of chemical properties with optical and climatic parameters of particulate matter in the area of Athens. PhD Thesis, Department of Chemistry, University of Crete.

Paraskevopoulou, D., Liakakou, E., Gerasopoulos, E., Theodosi, C. and Mihalopoulos, N. (2014). Long-term characterization of organic and elemental carbon in the $\mathrm{PM}_{2.5}$ fraction: The case of Athens, Greece. Atmos. Chem. Phys. 14: 13313-13325.

Paraskevopoulou, D., Liakakou, E., Gerasopoulos, E. And Mihalopoulos, N. (2015). Sources of atmospheric aerosol from long-term measurements (5years) of chemical composition in Athens, Greece. Sci. Total Environ. 527- 
528: 165-178.

Paredes-Miranda, G., Arnott, W.P., Jimenez, J.L., Aiken, A.C., Gaffney, J.S. and Marley, N.A. (2009). Primary and secondary contributions to aerosol light scattering and absorption in Mexico City during the MILAGRO 2006 campaign. Atmos. Chem. Phys. 9: 3721-3730.

Patel, P.N., Dumka, U.C., Kaskaoutis, D.G., Babu, K.N. and Mathur, A.K. (2017). Optical and radiative properties of aerosols over Desalpar, a remote site in western India: Source identification, modification processes and aerosol type discrimination. Sci. Total Environ. 575: 612-627.

Pateraki, S., Assimakopoulos, V.D., Bougiatioti, A., Kouvarakis, G., Mihalopoulos, N. and Vasilakos, Ch. (2012). Carbonaceous and ionic compositional patterns of fine particles over an urban Mediterranean area. Sci. Total Environ. 424: 251-263.

Pateraki, S., Asimakopoulos, D.N., Bougiatioti, A., Maggos, T., Vasilakos, C. and Mihalopoulos, N. (2014). Assessment of $\mathrm{PM}_{2.5}$ and $\mathrm{PM}_{1}$ chemical profile in a multiple-impacted Mediterranean urban area: Origin, sources and meteorological dependence. Sci. Total Environ. 479-480: 210-220.

Putaud, J.P., Van Dingenen, R., Alastuey, A., Bauer, H., Birmili, W., Cyrys, J., Flentje, H., Fuzzi, S., Gehrig, R., Hansson, H.C., Harrison, R.M., Herrmann, H., Hitzenberger, R., Hüglin, C., Jones, A.M., Kasper-Giebl, A., Kiss, G., Kousa, A., Kuhlbusch, T.A.J., Löschau, G., Maenhaut, W., Molnar, A., Moreno, T., Pekkanen, J., Perrino, C., Pitz, M., Puxbaum, H., Querol, X., Rodriguez, S., Salma, I., Schwarz, J., Smolik, J., Schneider, J., Spindler, G., ten Brink, H., Tursic, J., Viana, M., Wiedensohler, A. and Raes, F. (2010). A European aerosol phenomenology - 3: Physical and chemical characteristics of particulate matter from 60 rural, urban, and kerbside sites across Europe. Atmos. Environ. 44: 1308-1320.

Putaud, J.P., Cavalli, F., Martins dos Santos, S. and Dell'Acqua, A. (2014). Long-term trends in aerosol optical characteristics in the Po Valley, Italy. Atmos. Chem. Phys. 14: 9129-9136.

Rajesh, T.A. and Ramachandran, S. (2018). Black carbon aerosol mass concentration, absorption and single scattering albedo from single and dual spot aethalometers: Radiative implications. J. Aerosol Sci. 119: 77-90.

Reche, C., Viana, M., Amato, F., Alastuey, A., Moreno, T., Hillamo, R., Teinila, K., Saarnio, K., Seco, R., Penuelas, J., Mohr, C., Prévôt, A.S.H. and Querol, X. (2012). Biomass burning contributions to urban aerosols in a coastal Mediterranean City. Sci. Total Environ. 427-428: 175-190.

Remoundaki, E., Kassomenos, P., Mantas, E., Mihalopoulos, N. and Tsezos, M. (2013). Composition and mass closure of $\mathrm{PM}_{2.5}$ in urban environment (Athens, Greece). Aerosol Air Qual. Res. 13: 72-82.

Russell, P.B., Bergstrom, R.W., Shinozuka, Y., Clarke, A.D., De-Carlo, P.F., Jimenez, J.L., Livingston, J.M., Redemann, J., Dubovik, O. and Strawa, A. (2010). Absorption Angstrom Exponent in AERONET and related data as an indicator of aerosol composition. Atmos. Chem. Phys. 10: 1155-1169.

Saffari, A., Daher, N., Samara, C., Voutsa, D., Kouras, A., Manoli, E., Karagkiozidou, O., Vlachokostas, C., Moussiopoulos, N., Shafer, M.M., Schauer, J.J. and Sioutas, C. (2013). Increased biomass burning due to the economic crisis in Greece and its adverse impact on wintertime air quality in Thessaloniki. Environ. Sci. Technol. 47: 13313-13320.

Sandradewi, J., Prevot, A.S.H., Weingartner, E., Schmidhauser, R., Gysel, M. and Baltensperger, U. (2008). A study of wood burning and traffic aerosols in an Alpine valley using a multi-wavelength Aethalometer. Atmos. Environ. 42: 101-112.

Saraga, D.E., Makrogkika, A., Karavoltsos, S., Sakellari, A., Diapouli, E., Eleftheriadis, K., Vasilakos, C., Helmis, C. and Maggos, T. (2015). A pilot investigation of PM indoor/outdoor mass concentration and chemical analysis during a period of extensive fireplace use in Athens. Aerosol Air Qual. Res. 15: 2485-2495.

Sarigiannis, D.A., Kermenidou, M., Nikolaki, S., Zikopoulos, D. and Karakitsios, S.P. (2015). Mortality and Morbidity Attributed to Aerosol and Gaseous Emissions from Biomass Use for Space Heating. Aerosol Air Qual. Res. 15: 2496-2507.

Sarkar, C., Sinha, V., Sinha, B., Panday, A.K., Rupakheti, M. and Lawrence M.G. (2017). Source apportionment of NMVOCs in the Kathmandu Valley during the SusKat$\mathrm{ABC}$ international field campaign using positive matrix factorization. Atmos. Chem. Phys. 17: 8129-8156.

Schuster, G.L., Dubovik, O. and Holben, B.N. (2006). Angstrom exponent and bimodal aerosol size distributions. J. Geophys. Res. 111: D07207.

Schuster, G.L., Dubovik, O., Arola A., Eck T.F. and Holben B.N. (2016). Remote sensing of soot carbon Part 2: Understanding the absorption Ångström exponent. Atmos. Chem. Phys. 16: 1587-1602.

Sciare, J., Oikonomou, K., Cachier, H., Mihalopoulos, N., Andreae, M.O., Maenhaut, W. and Sarda-Esteve, R. (2005). Aerosol mass closure and reconstruction of the light scattering coefficient over the Eastern Mediterranean Sea during the MINOS campaign. Atmos. Chem. Phys. 5: 2253-2265.

Sciare, J., D'Argouges, O., Sarda-Esteve, R., Gaimoz, C., Dolgorouky, C., Bonnaire, N., Favez, O., Bonsang, B. and Gros, V. (2011). Large contribution of water-insoluble secondary organic aerosols in the region of Paris (France) during wintertime. J. Geophys. Res. 116: D22203.

Seinfeld, J.H. and Pandis, S.N. (1998). Atmospheric chemistry and physics: From air pollution to climate change. John Wiley, Hoboken, N.J., 1326 pp. 1998.

Srivastava, A.K., Yadav, V., Pathak, V., Singh, S., Tiwari, S., Bisht, D.S. and Goloub, P. (2014). Variability in radiative properties of major aerosol types: A year-long study over Delhi-An urban station in Indo-Gangetic Basin. Sci. Total Environ. 473-47: 659-666.

Stavroulas, I., Bougiatioti, A., Paraskevopoulou, D., Grivas, G., Liakakou, E., Gerasopoulos, E. and Mihalopoulos, N. (2018). Sources and processes that control the 
submicron organic aerosol in an urban Mediterranean environment (Athens) using high temporal resolution chemical composition measurements. Atmos. Chem. Phys. Discuss., in Review.

Stockwell, C.E., Christian, T.J., Goetz, J.D., Jayarathne, T., Bhave, P.V., Praveen, P.S., Adhikari, S., Maharjan, R., DeCarlo, P.F., Stone, E.A., Saikawa, E., Blake, D.R., Simpson, I.J., Yokelson, R.J. and Panday, A.K. (2016). Nepal Ambient Monitoring and Source Testing Experiment (NAMaSTE): Emissions of trace gases and light-absorbing carbon from wood and dung cooking fires, garbage and crop residue burning, brick kilns, and other sources. Atmos. Chem. Phys. 16: 11043-11081.

Tao, J., Zhang, L., Ho, K., Zheng, R., Lin, Z., Zhang, Z., Lin, M., Cao, J., Liu, S. and Wang, G. (2014). Impact of $\mathrm{PM}_{2.5}$ chemical compositions on aerosol light scattering in Guangzhoue the largest megacity in South China. Atmos. Res. 135-136: 48-58.

Theodosi, C., Grivas, G., Zarmpas, P., Chaloulakou, A. and Mihalopoulos, N. (2011). Mass and chemical composition of size-segregated aerosols $\left(\mathrm{PM}_{1}, \mathrm{PM}_{2.5}\right.$, $\mathrm{PM}_{10}$ ) over Athens, Greece: Local versus regional sources. Atmos. Chem. Phys. 11: 11895-11911.

Theodosi, C., Tsagkaraki, M., Zarmpas, P., Liakakou, E., Grivas, G., Paraskevopoulou, D., Lianou, M., Gerasopoulos, E. and Mihalopoulos, N. (2018). Multiyear chemical composition of the fine aerosol fraction in Athens, Greece, with emphasis on winter-time residential heating. Atmos. Chem. Phys. 18: 14371-14391.

Titos, G., Lyamani H., Cazorla A., Sorribas M., FoyoMoreno I., Wiedensohler A. and Alados-Arboledas, L. (2014). Study of the relative humidity dependence of aerosol light-scattering in southern Spain. Tellus $B$ 66: 24536.

Titos, G., del Águila, A., Cazorla, A., Lyamani, H., Casquero-Vera, J.A., Colombi, C., Cuccia, E., Gianelle, V., Močnik, G., Alastuey, A., Olmo, F.J. and AladosArboledas, L. (2017). Spatial and temporal variability of carbonaceous aerosols: Assessing the impact of biomass burning in the urban environment. Sci. Total Environ. 578: 613-625.

Tiwari, S., Dumka, U.C., Kaskaoutis, D.G., Ram, K., Panicker, A.S., Srivastava, M.K., Tiwari, S., Attri, S.D., Soni, V.K. and Pandey A.K. (2016). Aerosol chemical characterization and role of carbonaceous aerosol on radiative effect over Varanasi in central Indo-Gangetic Plain. Atmos. Environ. 125: 437-449.

Triantafyllou, E., Diapouli, E., Tsilibari, E.M., Adamopoulos, A.D., Biskos, G. and Eleftheriadis, K. (2016). Assessment of factors influencing PM mass concentration measured by gravimetric \& beta attenuation techniques at a suburban site. Atmos. Environ. 131: 409-417.

Vaishya, A., Singh, P., Rastogi, S. and Babu, S.S. (2017). Aerosol black carbon quantification in the central IndoGangetic Plain: Seasonal heterogeneity and source apportionment. Atmos. Res. 185: 13-21.

Valenzuela, A., Olmo, F.J., Lyamani, H., Antón, M., Titos, G., Cazorla, A. and Alados-Arboledas, L. (2015). Aerosol scattering and absorption Angström exponents as indicators of dust and dust-free days over Granada (Spain). Atmos. Res. 154: 1-13.

Virkkula, A., Backman, J., Aalto, P.P., Hulkkonen, M., Riuttanen, L., Nieminen, T., dal Maso, M., Sogacheva, L., de Leeuw, G. and Kulmala, M. (2011). Seasonal cycle, size dependencies, and source analyses of aerosol optical properties at the SMEAR II measurement station in Hyytiälä, Finland. Atmos. Chem. Phys. 11: 4445-4468.

Vrekoussis, M., Liakakou, E., Koçak, M., Kubilay, N., Oikonomou, K., Sciare, J. And Mihalopoulos, N. (2005). Seasonal variability of optical properties of aerosols in the Eastern Mediterranean. Atmos. Environ. 39: 70837094.

Vrekoussis, M., Richter, A., Hilboll, A., Burrows, J. P., Gerasopoulos, E., Lelieveld, J., Barrie, L., Zerefos, C. and Mihalopoulos, N. (2013). Economic crisis detected from space: Air quality observations over Athens/Greece. Geophys. Res. Lett. 40: 458-463.

Zhang, G., Bi, X., Chan, L., Wang, X., Sheng, G. and Fu, J. (2013). Size-segregated chemical characteristics of aerosol during haze in an urban area of the Pearl River Delta region, China. Urban Clim. 4: 74-84.

Zhang, Y., Ma, Y. and Gong W. (2017). Retrieval of Brown Carbon based on the aerosol complex refractive indices in the winter of Wuhan. Geo-Spatial Inf. Sci. 20: 319-324.

Zheng, W., Zhou, Y., Gu, H. and Tian, Z. (2017). Seasonal dynamics and impact factors of urban forest $\mathrm{CO}_{2}$ concentration in Harbin, China. J. For. Res. 28: 125-132.

Zotter, P., Herich, H., Gysel, M., El-Haddad, I., Zhang, Y., Močnik, G., Hüglin, C., Baltensperger, U., Szidat, S. and Prévôt, A.S.H. (2017). Evaluation of the absorption Ångström exponents for traffic and wood burning in the Aethalometer-based source apportionment using radiocarbon measurements of ambient aerosol. Atmos. Chem. Phys. 17: 4229-4249.

Received for review, November 30, 2017 Revised, June 11, 2018 Accepted, August 2, 2018 